Historic, Archive Document

Do not assume content reflects current scientific knowledge, policies, or practices. 



\section{Southern \\ Home Ground and Orchard Plantings}

Compiled under the direction of

The Southern Nurserymen's Association and presented to you with the compliments of

\section{Greensboro Nurseries}

JOHN A. YOUNG \& SONS, Owners

GREENSBORO, NORTH CAROLINA

Growers of Trees, Shrubs, Roses, Fruit Trees, and Vines for Southern Planting

Member of The Southern Nurserymen's Association 



\section{The Purpose of this Booklet}

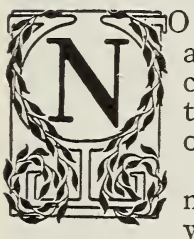

portion of our wonderful country offers greater natural advantages for beautiful home grounds and profitable orchards than does the South. Here the climate is agreeable to plant life, the soil is adapted to growing a large variety of trees and shrubs, and the moisture supply is sufficient.

Even with all these things in our favor, and with a great number of trees and shrubs that will grow almost anywhere, we really do not have the attractive home grounds that might be ours, nor do we, as a people, seem to know the value of such plantings. Too many of our people are content to live in a house set in the midst of sandy barrens, with never a tree to cast its welcome shade or a shrub to give fragrant flowers or a vine to screen the porch. Just a small sum would provide these simple comforts. On every home grounds deciduous trees should be planted for the shade they afford, shrubs for their graceful appearance and bloom, roses for their beauty and delightful fragrance, evergreens for windbreaks, and hedges and vines for screening unsightly objects.

To make the Southern home more beautiful and cheerful, the Southern orchard more profitable, and to assist the home-lover and orchardist to obtain better results from his plantings, is the aim of the Southern Nurserymen's Association. To help our friends and neighbors to have better home surroundings and more profitable fruit trees is the sole purpose of this booklet. It is not a catalogue, but a guide for Southern planters, prepared under the direction of men who have spent many years in growing the very things mentioned herein, and the information given is the result of their labor and experience.

The booklet has been written with the needs of the orchardist and homelover of the South especially in mind. There is nothing technical about the contents. It is written in every-day language, and if its simple directions are followed, you should experience no trouble in securing satisfactory results from your plantings.

The Southern Nurserymen's Association, under whose direction this booklet was prepared, is composed of the leading nurserymen of the South. The nurseryman who presents this booklet to you is a member of this Association. He stands ready at any time to help you in every way possible with suggestions and advice as to the proper planting of fruit trees and ornamentals. If you have some planting problem which you do not fully understand, do not hesitate to communicate with him. He is a practical grower himself, and his many years' experience will help you to make your planting more pleasing and profitable.

We are indebted to Mr. W. N. Hutt, State Horticulturist of North Carolina, for many helpful suggestions in preparing this booklet. 


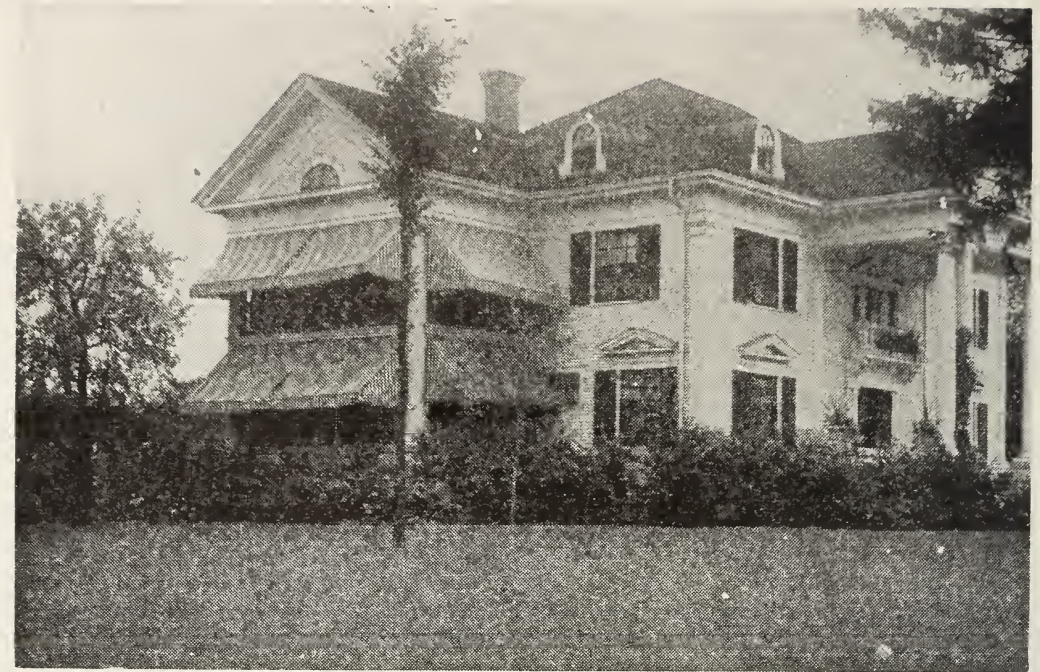

The lawn should be smooth and level, so no water can gather and stand

\section{The Lawn}

$\mathrm{T}$

HE scarcity of handsome lawns throughout the South is due more to improper preparation of the soil than to the long, warm summers. True, the seiection of the correct grasses has much to do with the success or failure of a lawn, but most failures are directly traceable to poor preparation of the soil - the foundation of every lawn.

The first thing we must have is drainage, for no suitable lawn grass likes wet feet. In ordinary soils sufficient drainage is obtained by securing the proper grade so that there are no hollows to allow the retention of water during "thaws." In unusually heavy or clayey soils, it may be necessary to lay underground tiles in lines about I 5 feet apart. The idea is not to strive for dry ground but rather to carry off all surplus moisture. By drainage we do not mean that the ground is to be kept dry, for grass cannot thrive without sufficient moisture. We simply mean that surplus moisture must be carried off, and not allowed to stand on the grass or about its roots.

The ground should be fairly rich. Eight inches of good soil (preferably loam) should be harrowed or spaded in and well mixed with a liberal quantity of dry, rotted manure; about 8 cords to the acre, or 2 or 3 inches deep, is the proper amount. All manure contains weed seeds to some extent, but it is necessary on some lands for the condition of the soil. In the proper amounts, it will make a sandy soil less porous and a clay soil more pliable and less liable to crack and bake during the dry spells. In spading or harrowing the ground, you should pick off and burn all the weed roots you can find, for smut grass or broom sedge will soon deface a lawn if it gets a start. Wild onions and rib grass, or narrow-leaf plantain, are other obnoxious pests.

The next problem is the selection of seed. Care must be taken in this, for the grass is the visible evidence of your labor and the thing that beautifies the ground. No one variety possesses all the fine points you must have, but there are several mixtures of the best sorts that are giving good results. Among these 


\section{SOUTHERN HOME GROUNDS}

perhaps the best is a combination known as evergreen lawn mixture. In this compound some of the varieties are at their best in early spring, others in the summer, and more late in the year. Thus you always have a nice green carpet of grass, whereas, if you sow but one variety, you get only one period of green grass each year.

To sow the seed, select a day when there is little or no wind, in order that the seed may not blow away. Scatter the seed carefully, so it will be distributed evenly. The proper time to sow is from September to November I5, or in early spring. After sowing, the lawn should be gone over thoroughly with a fine-toothed rake to cover and set the seed. Then it should be rolled, to firm the soil and make the surface level, for smoothness in a lawn is always desirable. After the grass is up a few inches, run the mower over it, leaving the cut grass to act as a mulch, and then roll the lawn. Rolling is as essential to good appearance as mowing, and should be done just as often, if best results are to be expected.

The best method for eradicating the weeds that appear is, to uproot them with an old knife. By encouraging the growth of grass with good care, we discourage the weeds, for

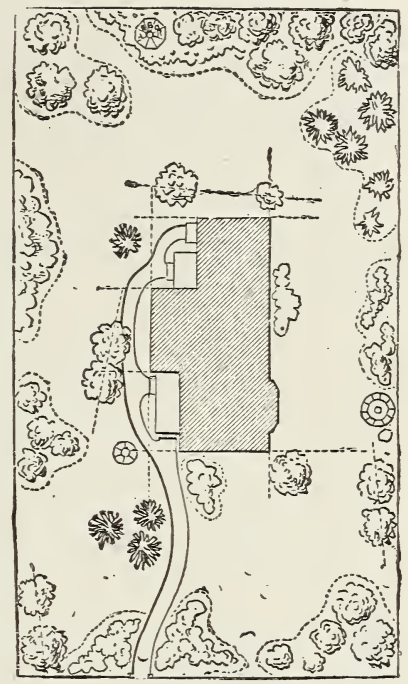

Fig. A they thrive most where the grass is thin and the soil poor. Old lawns should have a dressing of sheep manure in the early spring. In the fall a light top

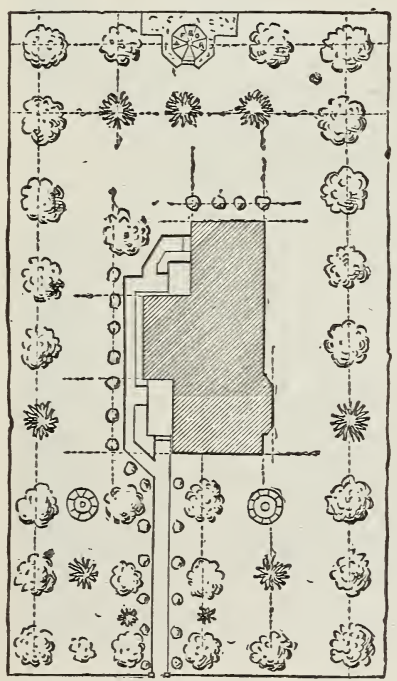

Fig. B dressing of wood ashes will be of lasting benefit.

A few pointers: Be sure of drainage; select a good seed mixture; do not be afraid to fertilize; mow and roll often; and, above all, if weeds get started, do not let them go to seed. Then you will have a good lawn.

\section{Laying Out the Grounds}

After having laid our lawn, the next step is to supply various units, such as drives, walks, gardens, and, maybe, a laundry yard, in such a way as to have them serviceable and still produce a harmonious whole. Bear in mind, throughout, that the chief service of the lawn and attendant trees and shrubs is to supply a setting for the more individual features of the grounds.

Either straight or curved drives and walks are proper on some places, but two general rules that it is safe to follow are: (I) Make them as serviceable and inconspicuous as possible, and (2) follow the contour of the ground. A noted horticulturist says: "Nature has but little use for the shortest distance between two 


\section{SOUTHERN HOME GROUNDS}

points; a walk that curves without visible reason is a mere wiggle and worse than straight lines." That is, should we desire a curved walk, it is best to supply some reason for the walk to curve, such as planting groups of shrubbery in the bends. A long, curved walk with appropriate plantings gives us a continual change of view and holds our interest.

Let us consider the two drawings of the same home grounds which are shown on page 3. Figure A shows a curved walk with a reason, well set out by shrubbery and evergreens. The straight walk in B is perfectly proper but very stiff and formal, and lacks the naturalistic effect seen in A. The trees and shrubs in the former are laid off in straight rows, covering the entire lot, leaving no open breathing places. The grounds, although as large as in A, appear much smaller and crowded.

In $\mathrm{A}$ the rule of mass planting and leaving the center open has been followed, allowing ample room for a fine greensward and views to all portions of the grounds. The mass or naturalistic planting is that of placing together several varieties that mass well. Individual specimens are used here and there to give variety by bright foliage or some other well-defined quality.

Prof. L. H. Bailey in his "Standard Cyclopedia of Horticulture" says: "Keep the lawn centers open. Plant in masses. Avoid straight lines." This is very good advice for any planter, and, if these rules are followed, a more handsome appearance on the home grounds will be the result.

Do not set out a tree or plant just because your neighbor did. What may look well on his place might not blend with your grounds at all. Make everything have a purpose, and, above all, do not crowd. A congested planting is merely a jumble instead of a picture. Evergreens, deciduous trees, shrubs, roses, etc., all have their proper place on the grounds, and the following pages will tell you about them.

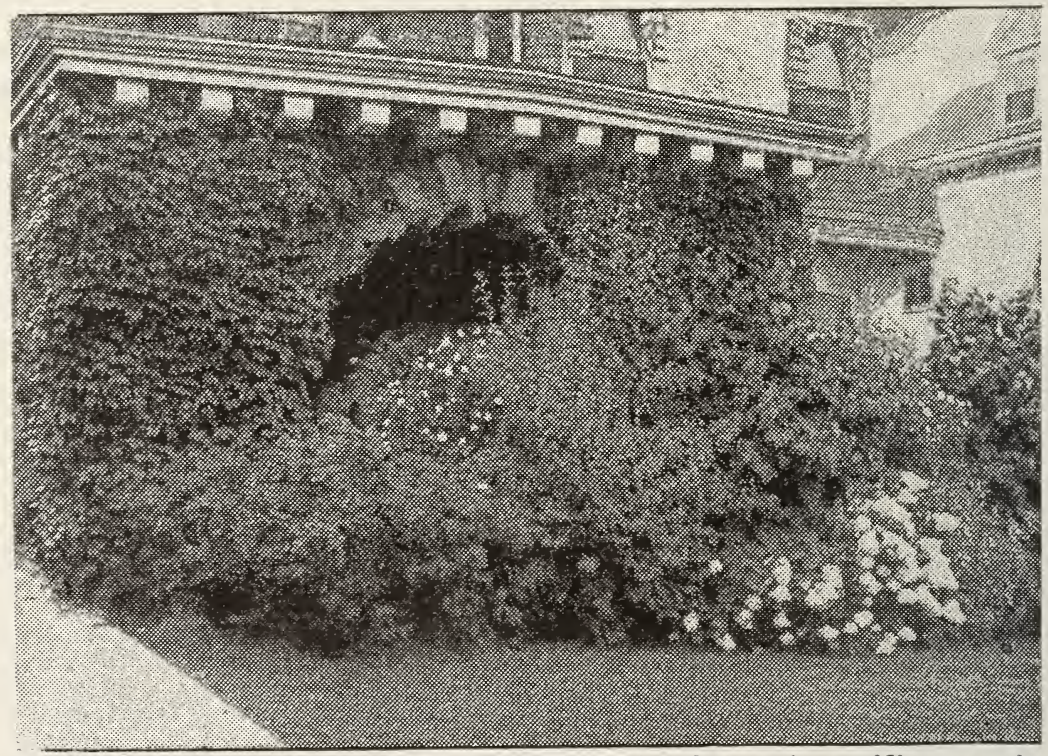

Ornamental plantings are much desired at the house foundation. At a trifling cost, the owner of this house increased its beauty a hundredfold 


\section{Ornamental Plantings}

The charm of ornamental plantings is one of the things that is not properly appreciated, but, for adding value to the home grounds and joy to life, they have a very high worth. Suppose you were about to buy a home. Would you buy a house surrounded by a few weeds or a rank growth of grass? Or, would you prefer a place that had a few trees, shrubs, or plants set out here and there? There is every chance that you would take the latter.

Now, in planting your grounds, first consider the foundation. Without plants the house stands out above the lawn, seeming to have no relation to it. There is nothing to soften the appearance and make the two blend. Before going any further let us examine the picture at the bottom of page 4. There are vines running up the wall and hiding its bareness. In the foreground there are a few shrubs neatly arranged which cover the bare foundation and give the house a really home-like appearance. The planting cost perhaps ten dollars or less, but does it not add considerably more than this to the value of the property? It is permanent, not requiring an annual planting and being in full foliage and flower before a planting of annuals would make any display.

Elaborate plantings should not be undertaken without the aid of a landscape architect. By this we mean plantings that are to cost considerable and are to be quite extensive in size. For the ordinary home a few dollars, invested in flowering shrubs, roses, and vines planted by your own hands, will give you greater joy than you can imagine. You will find it fun to plan your grounds, and then you will have them the way you prefer.

There are two very effective ways to set out the plants. One is to bunch them in clumps. This method is called "mass planting." The other way is to plant each separately. This is known as "specimen planting." Both methods are all right in their place, but ordinarily it is best to use the mass method for low-growing plants, and to plant the taller growing trees and use evergreens as specimens.

Your planting may be harmonious or contrasting. For harmony you can use plants whose leaves are the same shade of green or those whose flowers are nearly the same color. If the opposite is wanted, you will need some plants with dull green, some with bright green, and a few with variegated foliage. Variation in outline always adds interest. This is obtained by massing plants which grow to different heights. If due care is exercised in the selection of shrubs for these groups, a planting can be secured that will have some plant or group of plants at its best during the entire spring, summer, and fall. Broadleaved evergreens may be worked into the plantings to give a pleasing winter effect.

In all ornamental plantings, avoid straight lines; plant low trees and shrubs in masses, and taller ones as specimens; do not crowd or obscure attractive views; shut out undesirable objects by screens.

\section{Mass Plantings}

As shown on the preceding page, one good place for mass plantings is at the house foundations. There are many other places where they may be effectively used. On the boundary line of the grounds, on corners of the lawn, and at the bends of walks are good spots to put mass plantings. Figure $\mathrm{A}$ on page 3 shows a clump of evergreens massed at the curve in the walk. The planting should always be on the inside of the curve if it is on a small scale.

Shrubs (especially the low-growing kinds) should be planted in masses, and every home grounds should have a few clumps of them. The illustration on page 6 shows a neat planting beside a walk through the grounds. You may not care to spend the money for such an extensive planting as this, and it is not necessary, although this planting did not cost so much as you would think.

If you live in a city or village, a fence may now be separating your front 


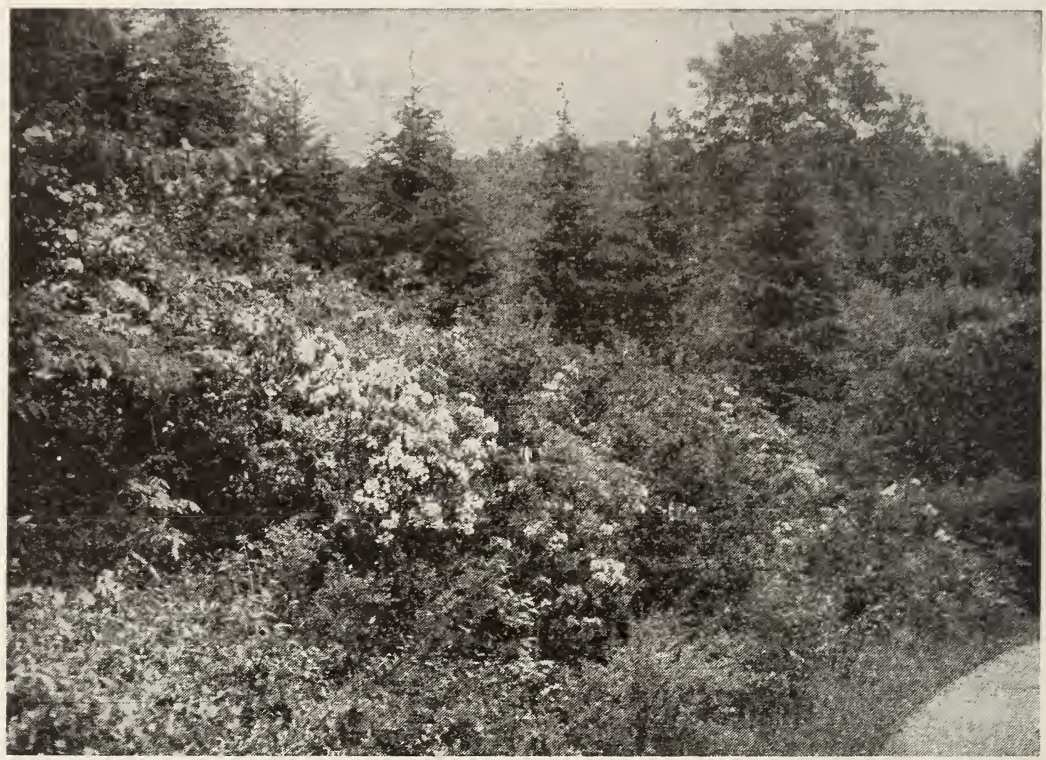

Along paths, walks or driveways mass plantings are far better than specimens

lawn from your neighbors. Where a row of homes are set nearly equi-distant from the street and each lawn is well kept up, fences and hedges are out of place. It is more charming to let lawns run into each other, forming one solid green carpet, with occasional specimens and masses about the homes. But, should some barrier be wanted, a neatly trimmed hedge of privet or a shrubbery border answers much better than a fence.

Talk it over with your neighbors. Tear down that fence and plant a shrub border or hedge. Doing this will make both homes more valuable and better places to live in.

Another good way to make a mass planting is to use perennials. They have a high decorative value and may be used in combination with shrubs, or alone as a foundation planting. Right up close to the house, plant the taller growing varieties, and in front plant the lower kinds. In this way your planting will "step down," as it were, toward the front, where, without any perceptible break, it will blend with the greenery of the lawn.

If you use perennials, be sure to plant those that will give variety, both in color of flower and period of bloom. Do not plant those of the same flowering period together, but place other plants between them. This will bring you extra joy, for it affords several months when some parts of your perennial border will be in bloom.

\section{Specimen Plantings}

By specimen plantings is meant the planting of single trees on the lawn, or, in fact, anywhere on the home grounds. Specimen plantings are also desirable in parks and cemeteries, but it is on the home grounds that their great worth should be more fully appreciated. Wherever shade is wanted, plant 


\section{SOUTHERN HOME GROUNDS}

specimen trees. They keep off the hot rays of the sun and afford an excellent place for the children to play beneath their spreading branches.

The illustration on this page shows a Crape Myrtle in a specimen planting. This gives an idea of how this beautiful flowering tree will appear on the grounds. It grows to about I 5 feet in height, and during almost the entire summer it is covered with charming pink flowers. Crape Myrtle is a typical Southern tree and for that reason it should be on every home grounds. It is not recommended so much for shade as for its value in ornamentation.

What trees to use depends largely on the individual taste and in what part of the South you live. The best way to find out just what you should plant is to ask the nurseryman who presented you with this booklet. Magnolias, Pecans, and Mimosa are useful. These are all good shade trees and are well adapted to our Southern soil and climate. The Pecan is extra valuable on account of its big crop of delicious nuts. The Oaks are good for shade trees and stand our Southern conditions well. The Planes, Dogwoods, Tulip Tree, Poplars, and the Ginkgo thrive in the South and should be widely used in specimen plantings.

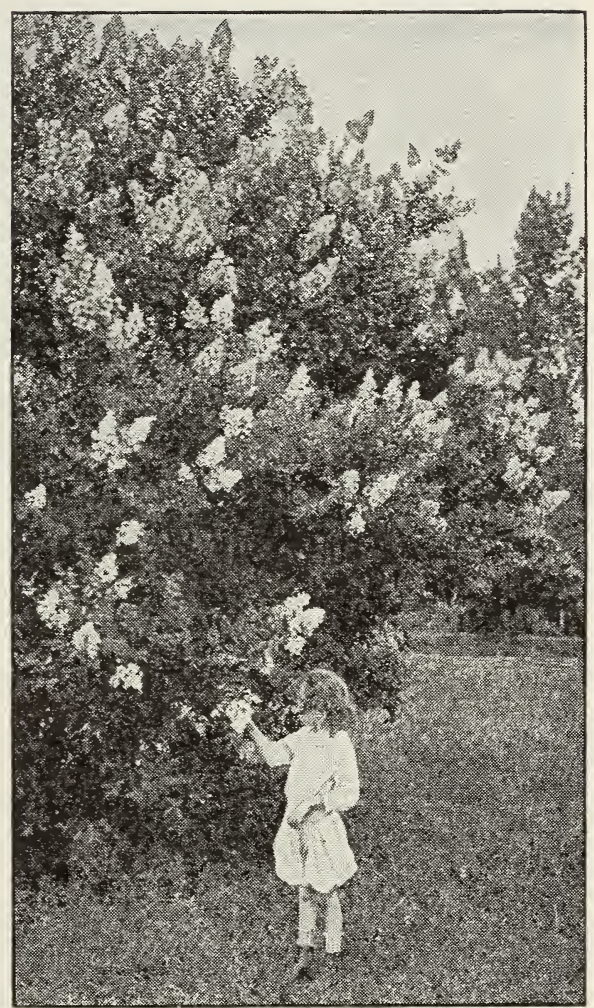

For specimen planting the Crape Myrtle is a most desirable tree for the South

\section{Deciduous Trees}

These trees get their name from the fact that they drop their foliage each fall and are dormant through winter. They are widely planted all over the world because of their beauty during the hot summer months. Most deciduous trees furnish shade and are therefore almost indispensable for home planting.

To obtain the best results with plantings of deciduous trees but little work is necessary. They like a mellow loamy soil, with sufficient moisture and good drainage, but they do not like to have water standing about their roots.

In selecting the varieties of trees, the location must be considered, for the kinds that thrive in one locality may not be satisfactory in another. The nurseryman who gave you this booklet can tell you what to plant for your particular locality. If you want your trees for shade and beauty, you can use the stately American Elm. This tree grows rapidly, and is one of the finest shade and ornamental trees you can have. Pecans grow well in the coastal South, but the Norway Maple is the best shade tree. 


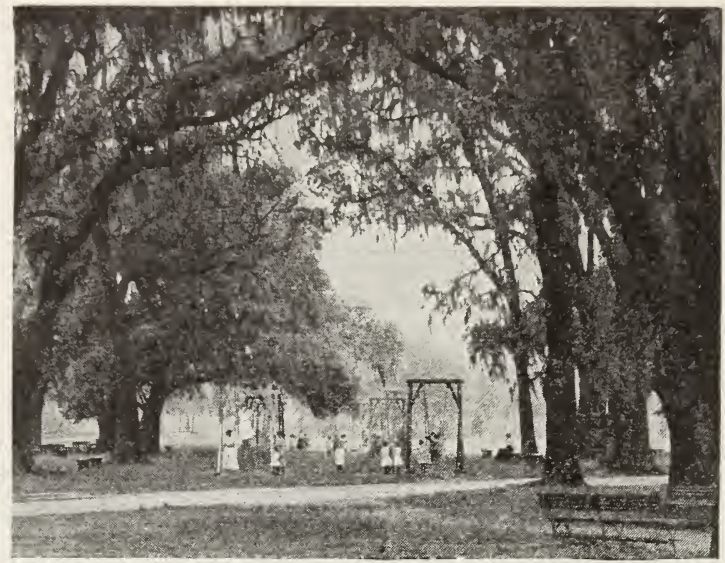

Deciduous trees are the most useful and appropriate for parks and playgrounds, and for shading the home
Another handsome small tree is the Crape Myrtle, a tree that every Southern homeowner should plant because it is typical of the South. The Mimosa is desirable on account of its delightfully fragrant foliage. The quickgrowing Lindens, with their abundant shade, make excellent lawn specimens. The Maples are always good on the lawn; the rapidgrowing varieties are Manitoba, Silverleaf, and Wier's Cutleaf. Sugar, Norway, Sycamore, and

Schwedler's Purple-leaf Maple are of slower growth. The Plane (Sycamore) trees are quick growers and in time reach immense size. The Oaks are slow to grow; but who can name a more majestic tree than a full-grown specimen? The Texas Umbrella is highly ornamental and at the same time possesses great value as a shade tree. The Judas Tree, Varnish tree, and Liriodendron, or Tulip Poplar, are also valuable lawn trees.

There is another class of trees that is not getting the attention it should have, and they are the weeping trees. Are you not always impressed by the beauty of the Weeping Willow? It grows quickly and gives universal satisfaction. Thurlow's Willow is similar and is truly a remarkable tree. Perhaps the most pronounced "weeper" of all is Teas' Mulberry. The branches of this tree are slender, pendulous, and droop to the ground in such a way as to give the tree a fountain-like aspect. All of these weeping trees do well in the South and are extremely valuable for decoration. The Weeping Willows are also excellent shade trees. Weeping trees, and those with odd-shaped and variegaced leaves should be an exception rather than a rule on all home grounds.

\section{Coniferous Evergreens}

For some reason or other we people of the South do not plant evergreens so widely as we should. Perhaps it is because we look on them as strictly northern trees and not adapted to the South. This is true of but very few.evergreens, for nearly every variety that will thrive in the North will also do well in the South. And, besides that, we have some native sorts that do far better here than in the North. The Australian Pine, while valuable for southern Florida, will not thrive outside of that state. The Deodar, or Indian Cedar, is another handsome tree that is satisfactory here, but not in the North.

For planting on the home grounds, evergreens have a great advantage over deciduous trees in that they are beautiful both summer and winter, while the deciduous trees are attractive in the summer only. Evergreens are hardy and will successfully withstand extremes of heat and cold. They do not require any care after planting, but like a fairly rich soil. Given this, there is every chance that they will live and thrive for many years if you will keep dogs away from them while the trees are small. 


\section{SOUTHERN HOME GROUNDS}

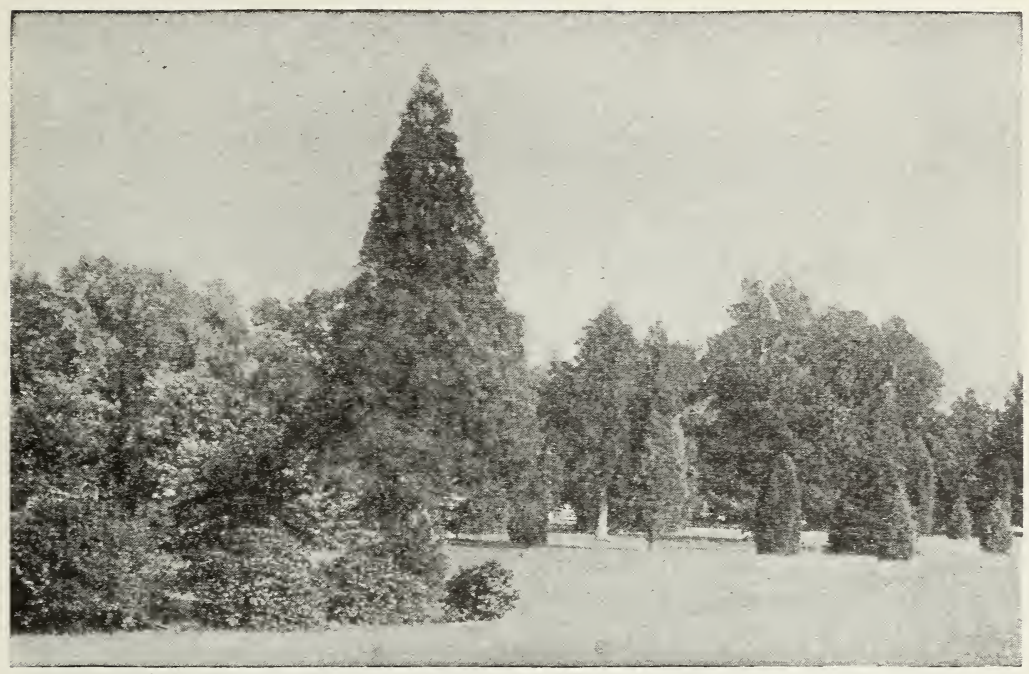

Coniferous Evergreens are much desired, for they are beautiful the year round

There are two good ways to plant evergreens, namely, in masses and as specimens. The plan you adopt should depend largely on the ultimate size the tree will attain. If it will reach any considerable size, specimen planting will prove more effective, while the low growers will look best in mass plantings. Then again, the color should be considered. The golden-foliaged trees make excellent specimens, regardless of size, and the same is true of all other trees with variegated leaves.

Let us consider the merits of some of the many evergreen trees that are adapted to the South. First of all is the handsome Indian or Deodar Cedar. This tree possesses a symmetrical, cone-like form and beautiful silvery foliage. It grows to great size, and is rightly considered one of the best trees for specimen planting. Of the other Cedars, the Mt. Atlas variety is perhaps the leader for specimen planting. It is a pyramidal, loosely formed tree, reaching a height of over Ioo feet. The Virginian and Blue Virginian Cedars are handsome trees. The Japanese Cedar is a stately tree, reaching 40 feet or more in height. The foliage is bluish green and the tree itself is a rapid grower.

Arborvitæs possess great value for either mass, specimen, or hedge planting. The American Arborvitæ grows tall, but a little trimming will train it to any desired size or shape. Its natural form is rather pyramidal, a characteristic which makes it useful in specimen planting, and, as it is easy to train, it is also an excellent hedge plant.

The Dwarf Golden Arborvitæ is a low variety, valuable for its wonderful golden foliage. It is a remarkable plant for specimen plantings, window boxes, or for lawn decorations. The American Fern-like Arborvitæ grows to about 20 feet, and has a spreading pyramidal shape. The foliage is bright green, deeply toothed, and held on the tree in such a way that the whole resembles a fern.

The Junipers do well, and they are useful both in specimen and mass planting. The Irish Juniper is perhaps the best for planting where an out-of-theordinary effect is wanted. Its green foliage is dense, and the branches grow 
erect and close to the trunk, giving the tree the appearance of a pillar. It is an excellent variety for planting in cemeteries. Any of the Junipers do well in the South and you need not hesitate to plant them.

Space will not permit us to point out the advantages of all the desirable evergreens for Southern planting; but you can set out any of the Arborvitæs, Firs, Junipers, Hemlocks, Cedars, Spruces, Pines, Retinosporas; and your selection should thrive. There are many different varieties of these and each sort has distinct advantages of its own. Ask us about suitable varieties for your locality. Some of the lower-growing evergreens make effective hedges, while the taller growers should be planted singly, in screens, or in clumps.

\section{Broad-Leaved Evergreens}

In considering evergreens for home-grounds planting, we must not overlook the broad-leaved types, for there are many of them suitable for either mass or specimen plantings. Among these is the beautiful Abelia grandiflora, a shrub of great value. The dark, glossy green leaves remain all winter, and the dainty, pinkish white flowers are borne in abundance from July until frost. For mass plantings on the lawn or at the house foundations, A. grandiflora is in a class by itself. Other desirable plants are the Camellia, Cape Jasmine, English or Cherry Laurel, the Japanese Privet, Holly-leaved Tea Olive, and the evergreen Mahonias. The Wild Orange, or Carolina Cherry, is also highly prized for general planting.

All broad-leaved evergreens are worthy of extensive planting, for they have many good qualities, and thrive under adverse conditions better than the cone-bearing kinds.

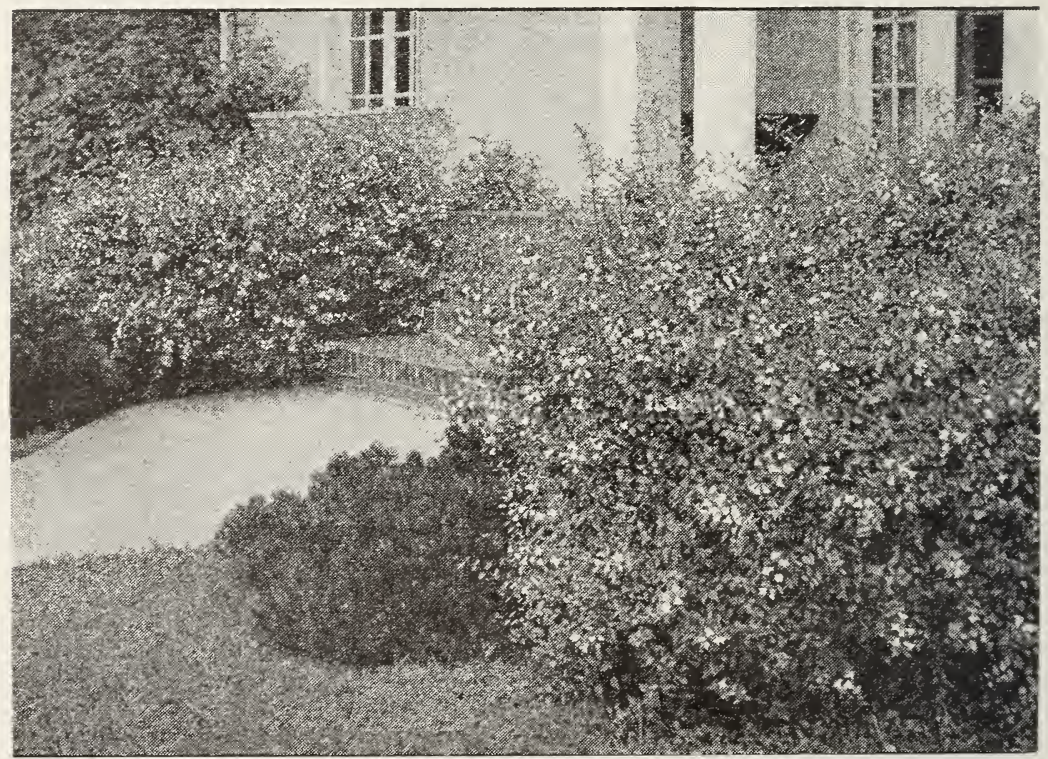

Abelia grandiflora used in foundation planting where it is most effective. Those dwarf evergreens look good too 


\section{SOUTHERN HOME GROUNDS}

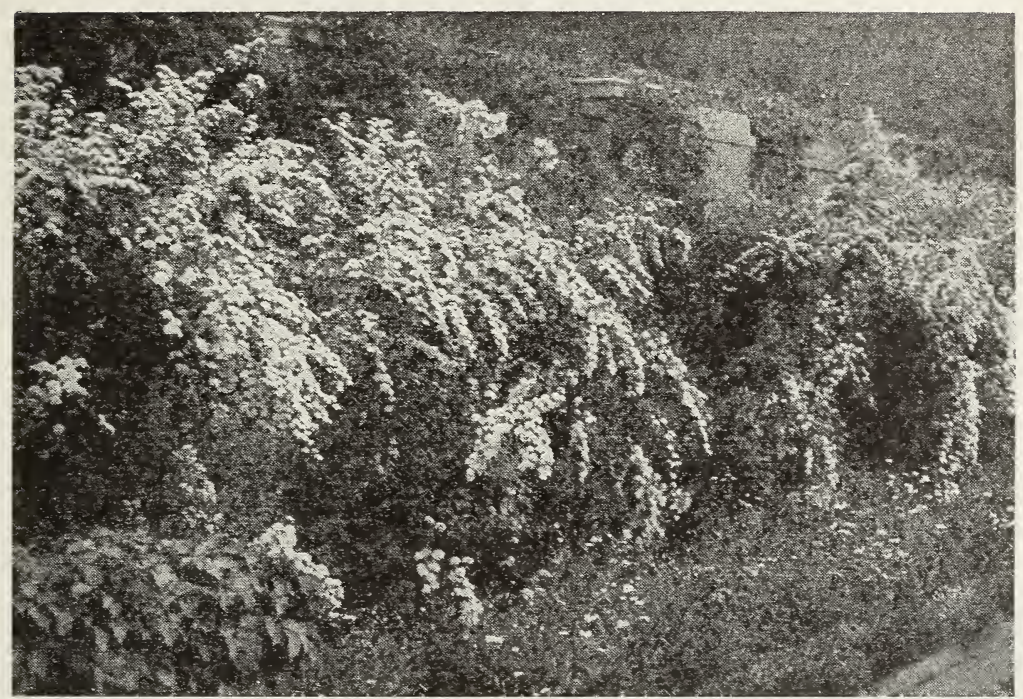

For flowering beauty we can hardly overlook the shrubs. A foundation planting of them has a distinct charm, for they improve the looks of the home

\section{Shrubs for Flowers and Foliage}

Without the strong colors and rich foliage of shrubs, many of the artistic and beautiful effects now obtainable in landscape planting would be lost. Few other plants seem to fit quite readily into every landscape plan. They are valuable for foundation planting, where they cover up bare walls and bring the lawn right up to the house without a visible break. In mass plantings they are very good and a clump of shrubs is an attractive sight when in flower.

Shrubs massed along walls and fences take away the ugly or bare appearance and make the grounds far more attractive. Some of the shrubs are ideal specimen plants and give excellent results when used this way. The Lilacs and Japanese Maples are appropriate for specimen planting and any of the taller kinds will appear well when planted singly.

In the corners of the home grounds are other good places for mass plantings of shrubs. A shrub border is far better than a fence between your grounds and those of your neighbor; it makes both grounds more attractive and more valuable. Some of the shrubs are useful in building hedges. The low-growing varieties can be used for this.

Among the deciduous shrubs that have proven themselves well adapted to our conditions are Althea, Barberry, Buddleia, Deutzia, Forsythia, Elæagnus, St. John's-Wort, and Tamarisk. The Calycanthus, or Sweet Shrub, Pearl Bush, Red-flowering Dogwood, Naked-fiowered Jasmine, Cytisus laburnum, White Kerria, Coral Berry, Chaste Tree, and the Hydrangeas, Bush Honeysuckles, Lilacs, Mock Oranges, Spireas, Snowballs, and Weigelas are others of value.

Both the deciduous and evergreen shrubs are widely used in all parts of the country, but nowhere are they more at home than in the South. However, it is well to know just what shrubs are best for your locality, and any Southern nurseryman will be able to tell you just what you should plant. Remember this, however, that the best way to arrange shrubs is in masses. 


\section{Roses - The Symbols of Sweetness}

Roses - the very name thrills all who love the fragile beauty of the "Queen of Flowers." And in the South this is especially true, for many of us have known the Rose since childhood. The Rose loves the sun, and in our long, warm summers it seems to thrive with utmost splendor. There is nothing gorgeous about this flower, but in a beautiful garden no other can take its place.

There are many varieties of Roses suited to our Southern soil and climate. Hybrid Tea, Hybrid Perpetual, Tea, and Climbers are the best known classes, although there are others of lesser note. Hybrid Perpetuals flower in great abundance during June, and perhaps bear a few blooms in August or September. They are delightfully fragrant. If the blooms, with stems of liberal length, are cut from the plant after the buds open, they will keep for several days if the stems are placed in water. This class of Roses is hardy and needs no winter protection.

The Tea varieties get their name from the marked tea-like fragrance prevalent in the blooms. They blossom from June until fall, and are quite valuable as cut-flowers. The Hybrid Teas are crosses of the hardy Hybrid Perpetuals and the free-flowering Teas, and possess the good qualities of both parents. From the former they get fragrance and hardiness, from the latter they get their long period of bloom. From early June until frost puts an end to their activities your Hybrid Tea bushes will bear handsome flowers of wonderful fragrance and almost fairy-like delicacy. There are several families of Climbing Roses, Noisettes, Wichuraianas, and others. All have their individual advantages, and a planting of any of them will please the lover of Climbing Roses. This class is very useful in the South, or anywhere else for that matter, for they can be used around the porch, where they temper the sun's rays with their shade and make the veranda more pleasant with their delightful fragrance. The Ramblers are useful for hiding stones, stumps, or other unsightly objects, and for covering up banks and terraces.

The "Queen of Flowers" likes rich soil, plenty of moisture, and abundant sunlight. Roses should not be planted in ground where there are roots of living trees.

Roses should be planted when they are dormant. Just before the ground freezes or in early spring are the proper periods for setting out the bushes. After deciding on the size of your Rose-bed, take out the soil to a depth of about 2 feet. If you are not absolutely sure about drainage, fill in the bottom with about 8 inches of small stones or pieces of brick. Now fill up the

There should not be a Southern home without its garden of fragrant Roses trench with good fertile soil mixed with 


\section{SOUTHERN HOME GROUNDS}

fertilizer. If cow-manure is available, you will find it the best, but it should be well rotted. Equal parts of cow-manure and soil is the correct proportion. If you use sheep manure or commercial fertilizer, use sparingly, for both are very strong, and an excess is liable to injure your plants.

You are now ready to plant your bushes. Set them with the splice (if they are budded varieties) about 2 inches below the surface. The hole that is to receive the plant should be large enough to allow the roots to be inserted without touching the sides. Now that you have set the plant, spread out the roots and do not allow them to lie across each other. With the hands gently firm the soil about the roots, for they can draw no substance from air spaces. Put in the top soil and pack it gently with the foot. If the ground is not quite moist when you plant, and it is not likely to be, pour a pail of water in this depression.

Your Roses are now set out and the next thing to do is to prune the bushes. If you plant in the fall, do not cut back very much of the live wood. Cut off any and all decayed wood and spindling branches, for these are weaklings and are only sapping away the life of the plant. If it is spring, cut back your plants severely. Select a good strong eye on the outside of the stem about a foot from the ground, and cut off the bush just above the eye.

It must be remembered that Roses have enemies, just as fruit trees have theirs. Directly after the leaves have opened, look at them and if any are stuck together or doubled up, that is the sign of Rose caterpillar. No remedy has been found to check this pest so well as pinching the glued leaves between the fingers. Do this every day until there are no further evidences of the caterpillar's activity. If the Rose bugs attack your plants, picking them off by hand will be most effective. Many of the leading Rose-growers plant a small, white-flowering shrub nearby, for Rose bugs are fond of white flowers and will go to the shrub. A good preventative of insect attacks is tobacco vapor. Place a few dry stems on the ground under the bushes and the vapor arising from them after a rain or sprinkling will do much to keep the insects at bay.

We are fully conversant with the culture and care of Roses. If you desire any information not given in $t h$ is booklet, we shall be glad to have you write us.

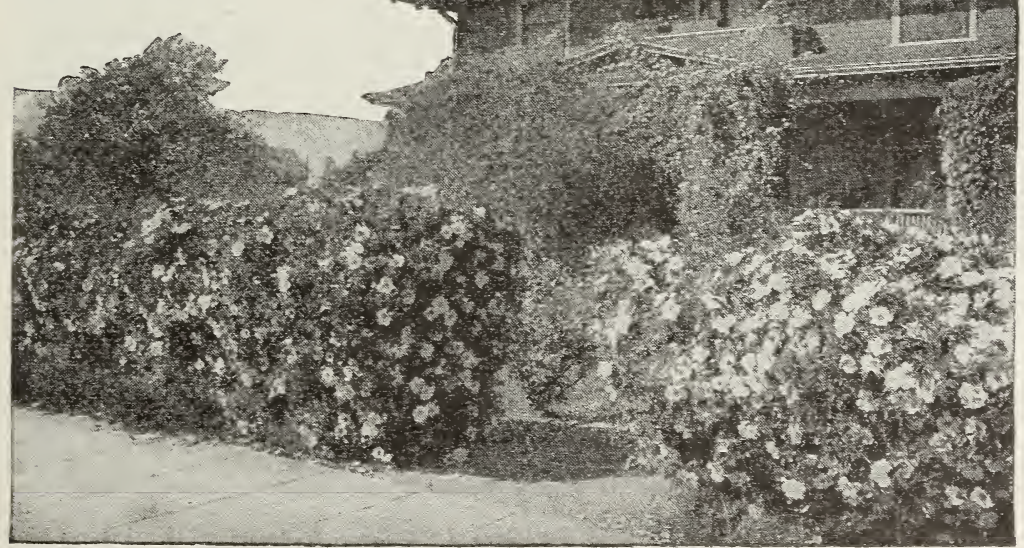

Climbing Roses and vines have much the same uses. Train them over the porch or on a wall where they will add much to the appearance of the house and grounds 


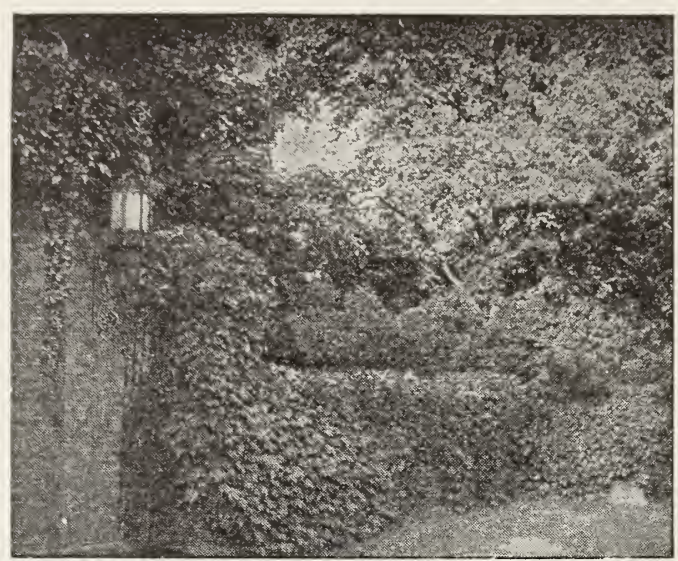

Just imagine the ugliness of this wall if that vine did not hide its bareness

\section{Vines and Creepers}

In ornamental plantings Vines have a multitude of uses. It seems that a planting of them always adds a mellowness to any scene. On new buildings they take away the glaring newness and make them blend with the landscape to a greater extent in a shorter time than any growing or blooming plant we can think of.

Let us consider how to use Vines. As porch draperies and screens they keep off the sun and make the porch more pleasant. For covering the walls and corners of the house, Vines are the only things that can soften the sharpness of the outlines. Look at the illustration on this page and imagine how that stone wall would look without Vines. The English Ivy helps wonderfully here, but a Wistaria, Kudzu Vine, Boston Ivy, Dutchman's Pipe, Clematis, Jackson Vine, or Honeysuckle would be just as effective.

Vines grow rapidly, some of them sending out shoots 50 feet long in a year. The foliage of most varieties is quite dense, and nearly all of them produce an abundance of dainty flowers, some of which possess a pleasing fragrance. All vines belong to one of two classes, evergreen or deciduous. There is little to choose between the two, and a selection from either class will prove of great value. Both like rich soil, and, if given this, you need not worry much over the ultimate success of the planting.

However, we must bear in mind that the habits of the evergreen varieties differ from those of the deciduous kinds. The former seem to prefer a halfshady location for they do better where the sun's rays do not strike directly. The deciduous sorts, on the other hand, always revel in the open sunlight and are in their glory when they are not shaded at all during the day.

Now do not think that evergreen Vines must be kept in the shade and the deciduous varieties in full sunlight, for such is far from the case. Vines will grow anywhere and will do well if given only half a chance; but, like everything else, the better the opportunity they have, the better the results you may expect.

\section{Plants that Live from Year to Year}

All plants are divided into three general classes: Annuals, or those that start from seed, bloom, and die in one season, like Asters; Biennials, or those that require two seasons to complete their life, like Hollyhocks; Perennials, or those whose roots live in the ground year after year, although the tops die down to the ground in the fall.

Owing to their ability to thrive in almost any climate, perennials are extensively planted all over the country, but we people of the South should plant them more, and perhaps we would if we fully understood their remarkable advantages. 


\section{SOUTHERN HOME GROUNDS}

In the first place, they are the cheapest of all plants, for, unlike the annuals, they do not have to be replanted each year. A planting of perennials is like a planting of shrubs or trees, for it increases in value each succeeding year; but, unlike them, perennials do not require a couple of years' growth before they take their place in your garden plan.

There are many ways in which plantings of perennials may be used effectively. Beds, borders, and edgings are the principal ways to plant them, and any of these plans will give good results. Perennials should always be planted in masses, for a single plant does not show up the beauty of flower and foliage.

Perennials readily lend themselves to foundation planting. In such arrangements it is usual to plant the tall-growing varieties close to the house, the lower growers in front, and the dwarf varieties in the immediate foreground. This gives a planting that "steps down" and blends with the lawn. In planting a border the same scheme should be followed. Always select the sorts that will give variety in both color of flowers and period of bloom. Suppose you set out varieties that will flower in succession. Some will bloom in spring, others in early summer, more in late summer, and, when fall comes, others will be in blossom. This will give you a garden that will have flowers in it all through the warm weather.

A few of the best perennials, adapted to our conditions, are Columbines, Coreopsis, Hardy Larkspurs, Hardy Pinks, Sweet Williams, Foxgloves, Gaillardias, Iceland Poppies, Phloxes, and Chinese Bellflowers.

Peonies are valuable perennial plants. They are hardy, and the flowers are large and of the utmost beauty. September is the best time to set them out, for it gives them an opportunity to become established before winter. Peonies will thrive in any good ordinary soil and they require almost no care. Set the plants with the eyes 2 or 3 inches below the surface of the ground. A little cultivation and the liberal use of manure will produce a result of greater beauty in flower and greater freedom of bloom.

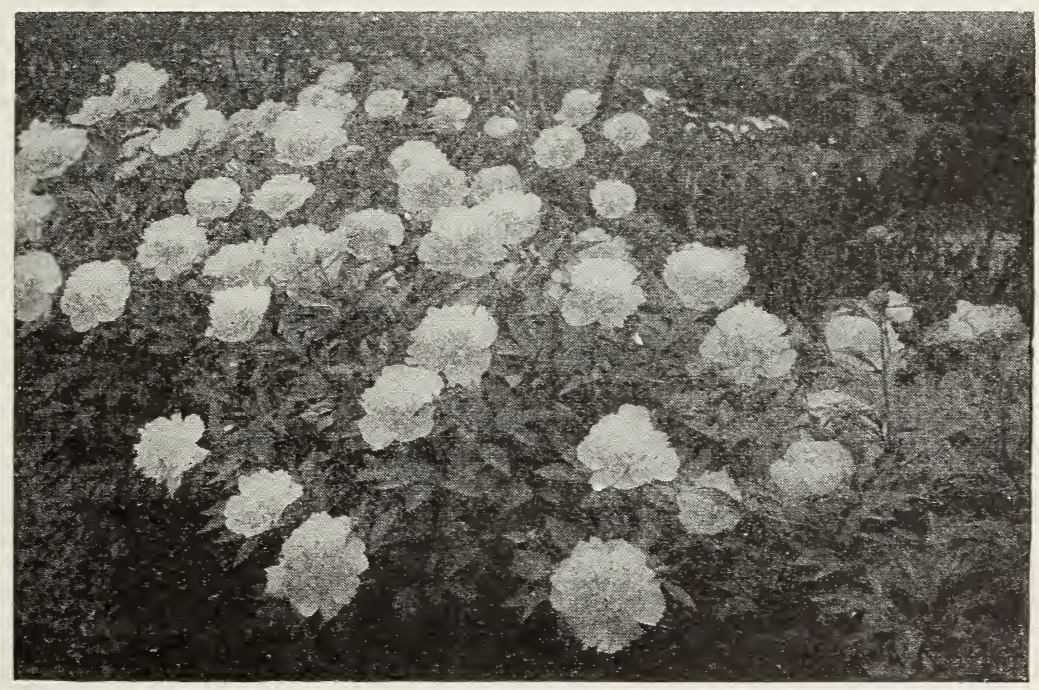

Among perennials there are no flowers that possess so many distinct characteristics as Peonies. Their flowers are larger than those of the Rose, and nearly as beautiful 


\section{Pecans}

A Texas paper praises the Pecan in these glowing words: "In this country the clean and strong form of the Pecan proclaims it the aristocrat among trees. Its symmetrical form, its graceful branches, its straight trunk, and its foliage make it a thing of beauty. As a shade or ornamental tree it has no superiors, and its long life teaches us the important lesson of preparing pleasures for coming generations.

"Its shade is not so dense as to wither out the grass underneath but is dense enough to keep off the sun's rays when the mercury is around a hundred in the shade. Nut trees about the home, in addition to their beauty, are very dear to the hearts of our youngsters, and are one of the links that bind them to their home. A few Pecan trees around the home will furnish you with shade, make the grounds more beautiful, and put money in your pocket."

The trait that most recommends the Pecan tree is its worth as a profitproducer. Plant a young tree now; in a few years it will bring in big money, and it will steadily increase in worth. After the tree starts bearing nuts, its yield will increase annually until forty years after planting, and then it will continue its maximum crops indefinitely. In fact, there are trees bearing now that are known to be over one hundred years old.

Some people are troubled with the bugaboo of "over-production," and are not planting Pecans for that reason. Nothing could be further from the truth, for the demand is increasing yearly and the field is continually becoming more extensive. One of the South's noted horticultural authorities says: "The most promising item in the nut field at the present time is the fact that nuts are being consumed in larger quantities than ever before. The demand for fancy

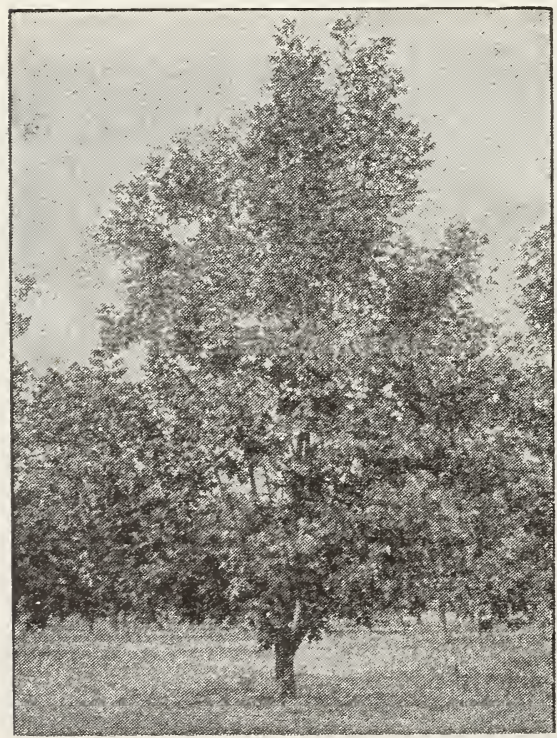

Pecan trees are useful both for their shade and profitable nuts dessert nuts is steadily increasing. Growers are not better able to supply the demand now than formerly, even though their output has increased. Prices have at the same time steadily advanced. An oil far superior to olive oil is now made from the Pecan."

Another advantage which the Pecan possesses is its marketing period. The nuts can be marketed any time during the twelve months after ripening, for they are not perishable and will stand any amount of shipping.

In regard to the profits made from Pecans, we can tell the story best by reproducing a few letters from enthusiastic growers. Mr. West, of Monticello, Fla., says: "I got 900 pounds of nuts from one tree, which I consider worth $\$ 500$. My I 2-year-old tree earned $\$ 54$ last year." Dr. Morris, of New York, writing in "Medical Council," says: "More than $\$ 200$ has been paid tor the crop of a single Pecan tree in a single year. Anyone can have an income of a few thousand dollars per year if he really cares to bring his initiative 


\section{SOUTHERN HOME GROUNDS}

to bear on the subject." These statements are based on facts and made by men who know. They should command the attention of every enterprising farmer and planter in the South. The President of the Nut Growers'Association said: "I saw a Pecan tree in Mexico, 5 feet in diameter, that is said to bear, every year, over a ton of nuts."

Now, let us consider the value of the different varieties of Pecans. Curtis is a medium-sized nut, and is considered one of the best for home planting. The shell is thin and the kernel has an excellent flavor. The tree is healthy and a good bearer. Delmas is slightly larger than Curtis, a good commercial variety, and the shell is a little thicker. The kernel is larger and of excellent quality. Schley is considered by many to be the leading commercial variety. The nut is large and the shell is very thin, brittle, and easily cracked. The kernel completely fills the shell; its quality is excellent. Schley is one of the hardiest varieties. Stuart is another good commercial variety. The nut is large, the shell is rather thick, the kernel fills the shell well, and its flavor is good. Van Deman is a large nut, with a medium-thin shell, and has a good quality of kernel. The tree is a very shy bearer.

Among the more hardy varieties, Indiana, Mantura, and Money-maker are considered to be superior. The nuts are medium-sized and the kernels are of high quality. These sorts may be safely planted in the colder sections of the South and even as far north as Richmond.

Almost any land in the South Coastal region that will successfully grow farm crops will produce Pecans. The trees should be transplanted in winter when they are dormant. Do not allow the roots to be exposed to the sun when transplanting. If the soil is stiff and clayey, dynamite should be used to dig the holes. Ask the Dupont Powder Company, Wilmington, Delaware, for their booklet, "Dyramite on the Farm." Dig the hole big enough to allow the roots to pass into it without touching the sides. Cut off the ends of the roots but leave the top alone. Set the tree at the depth it stood in the nursery and pack the soil firmly around the roots. Settle the dirt with water and put a mulch over the earth around the tree to help retain the moisture. In dry times water the young tree. Follow these few instructions and your trees should do very well.

To get the highest prices the nuts should be polished and graded. Do not pack nuts of different sizes in the same package. It is better to market them separately, for they will then bring the best prices.

Both trees and nuts are fairly free from insect pests. This fact should claim the attention of the cotton-planters who have fearfully watched the havoc wrought by boll-weevil.

If you wish any further information on the planting, care, or cultivation of Pecans, write us, asking any questions you wish. We will attend to your request promptly and will gladly tell you what we can.

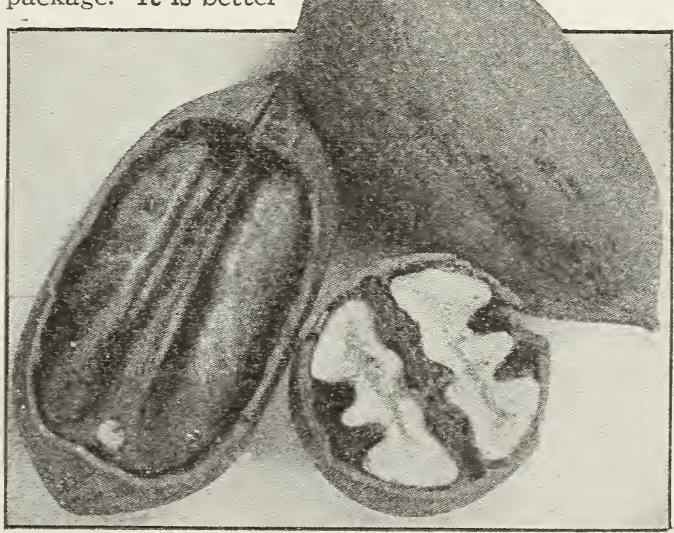

There's money in Pecans for the Southern planter 


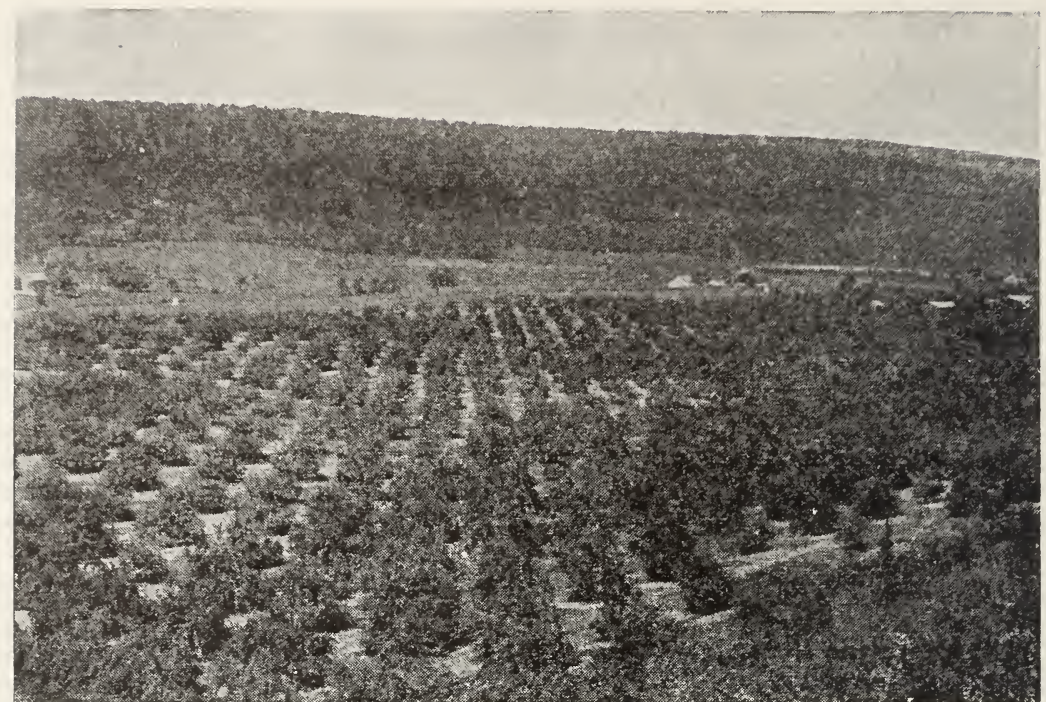

An apple orchard is five times as valuable as the same land planted to wheat, corn or cotton

\section{Fruits for the South}

\section{Apples}

If there is any fruit that may be called a general favorite all over the country, it is the Apple. The trees are hardy, easy to grow, and the fruit is one of the most pleasing. For home use Apples will give you fruit from early summer until the following spring, if you plant the right varieties. If you grow for market, you will always get excellent prices for choice fruit, for there is an everincreasing demand for good Apples. An orchard does not cost much to plant and keep up, is easy to handle, and a good one is a money-maker; in fact an apple orchard is worth five times as much as grain on the same land. No matter whether you grow for your own use or for sale, you should have an Apple orchard.

In selecting varieties, you should get some that ripen their fruit in early summer, others in late summer, and more in fall. This will give you fresh fruit over a much longer period. The leading summer Apples for either home or market use are Red Astrachan, Red June, Yellow Transparent, Early Harvest, and Horse. Among Apples that ripen in autumn, Bonum, Fall Pippin, Grimes, and Buckingham are the best for general use. There are numerous winter Apples. For the home orchard Delicious, Kinnard, Paragon (Mammoth Black Twig), Rome Beauty, Stayman Winesap, Yates, and York are among the best. Any of these are good commercial sorts.

Apple trees like a soft mellow soil where there is adequate drainage. Almost any soil that will grow good corn or cotton will give excellent results under Apples. The trees should be set out when dormant. The fall is a good time. The hole to receive the tree should be about 3 feet in diameter and 18 inches deep. Work the soil until it is mellow. See that all roots lie as they did in the nursery and then firm the earth about them. If any roots are bruised or 


\section{SOUTHERN ORCHARD PLANTINGS}

broken, they should be trimmed off smoothly with a sharp knife. While filling in around the roots, shake the tree occasionally to help settle the soil.

When the hole is two-thirds full, pour in two or three pails of water. After the water has soaked in, fill the hole, but do not pack the earth. Simply cover it with a mulch of straw or litter.

\section{Peaches}

The Peach is today, without doubt, the best fruit for general planting all over the South. The orange may be better for Florida, but outside the orange belt the Peach is the leader both for home consumption and for market. This fruit has a range of latitude exceeded in extent only by the apple. Many different varieties are grown successfully and profitably as far north as the Great Lakes, and in semi-tropical Florida you will find Peaches grown in great numbers. Of course the same varieties that make money for the man in Florida are not suited for growing in New York, but there are so many different kinds that it is easy to select the proper ones for your section.

People demand Peaches and, in spite of the fact that the trees are largely planted, the supply has never caught up with the demand. This demand is due to the excellent flavor of the fruit, and its value for preserving. The trees are easy to grow, and as they bear enormous loads of luscious fruit in a few years after planting, they should be set out in greater numbers by the folks of the South. The first fruit to reach the markets from northern orchards does not arrive until the first or middle of July. Peaches grown in the South reach the markets in May. This gives the man of the South two extra months to market his Peaches at a time when northern-grown kinds are not to be found. Right here is an excellent reason for more extensive planting of Peach trees in the South.

There are many varieties of Peaches suited to the South and, if a proper selection is made, you can have fresh fruit from May to October. Of course, some varieties are better for home use and others will prove more valuable market fruits. Let us first consider the sorts that are valuable for both purposes. Mayflower is without doubt the earliest. The tree is vigorous and needs watching or it will bear too much fruit. Ordinarily about half of the young fruits should be removed from the tree when they are about a half-inch through.

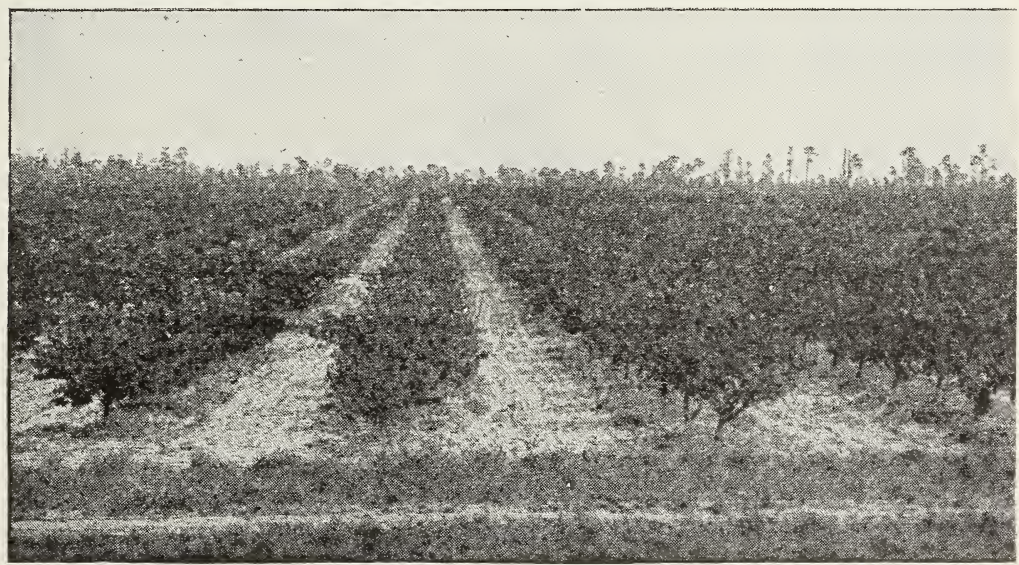

A Peach orchard like this will buy you an automobile and several other things 
Alexander is the next to ripen, soon followed by Greensboro and the Arp. Both are large fruits with delicious flesh. Carman, Hiley and Belle come next. All of these are of the highest class. Other valuable varieties are Elberta, Red Bird Cling, Champion, Chinese Cling, Heath Cling, Salway and Krummell. All these are high-quality fruits and will prove excellent sorts for home use. The new J. H. Hale Peach is another excellent variety, perhaps the best recent introduction.

Peach trees will thrive on almost any soil that will raise good standard farm crops, but of course the richer the soil, the better will be the reward. In laying out the orchard you should take the highest ground, and, if possible, plant where the earth slopes to the north or west. If your orchard is a little higher than the surrounding ground, you are almost certain to have good drainage. The trees should be set between I5 to 20 feet apart each way, so they will have plenty of room to develop and expand. The ground between the trees should be kept cultivated if you are looking for the best results. Plant about three rows of cowpeas between the rows of trees and do not cultivate so close as to injure the roots, bark the trees, or break the limbs. When the cowpeas are killed by frost, plow them under. They add nitrogen to the soil and make excellent food for the growing trees.

The presence of the Peach-tree borer, perhaps the worst enemy of the Peach tree, is indicated by the appearance, at or near the ground line, of a mass of jelly or sawdust, or both. In April and May and again in September, hoe away the soil from around the tree and examine closely for these signs. With a sharp knife cut away the bark exposing the hole and with a flexible wire search for the borer, spearing and removing it. A few minutes spent on each tree twice a year will thoroughly control this pest.

\section{Pears}

Pear trees like a fairly good soil and will do well in either clay, loam, or gravel. The ground should be well drained, so if you plant your orchard on sloping ground, your yield is almost sure to turn out much better. It is not a good policy to have your orchard close to a forest on account of the insects.

There are several varieties worthy of extensive planting. For home use and market we find that Koonce, Seckel, Le Conte, Kiefier, and Magnolia are the most satisfactory and ripen in about the order named. For the home orchard rather than for commercial purposes, the best sorts are Early Harvest, Seckel, and Angouleme.

\section{Plums}

This is another valuable deciduous fruit, growing over as wide a territory as the peach. The tree requires much the same soil and care that should be given all fruits, but if there is considerable clay in the soil, better results may be expected. The trees should be planted about i 8 feet apart each way and cowpeas or other crops may be raised between the trees. You may also grow strawberries as an intercrop, but if the cowpeas are plowed under after they are killed by frost, they will help the trees to grow and make them more vigorous.

It is generally conceded by growers that the Japanese varieties and their hybrids are by far the best for general planting. In their order of ripening the recommended varieties for the home orchard are Red June, Abundance, Satsuma, Burbank, and Wickson. All these, with the exception of Satsuma and Wickson, are excellent market sorts. Wild Goose is another excellent sort. If in doubt about the proper varieties, consult us.

On account of their heavy bearing characteristics, many Plum trees are greatly injured. Take a look at almost any tree you see in the home orchard; in fruiting time you will see the branches bent down to the ground and the tree almost staggering under its heavy load of fruit. Many people feel proud of 


\section{SOUTHERN ORCHARD PLANTINGS}

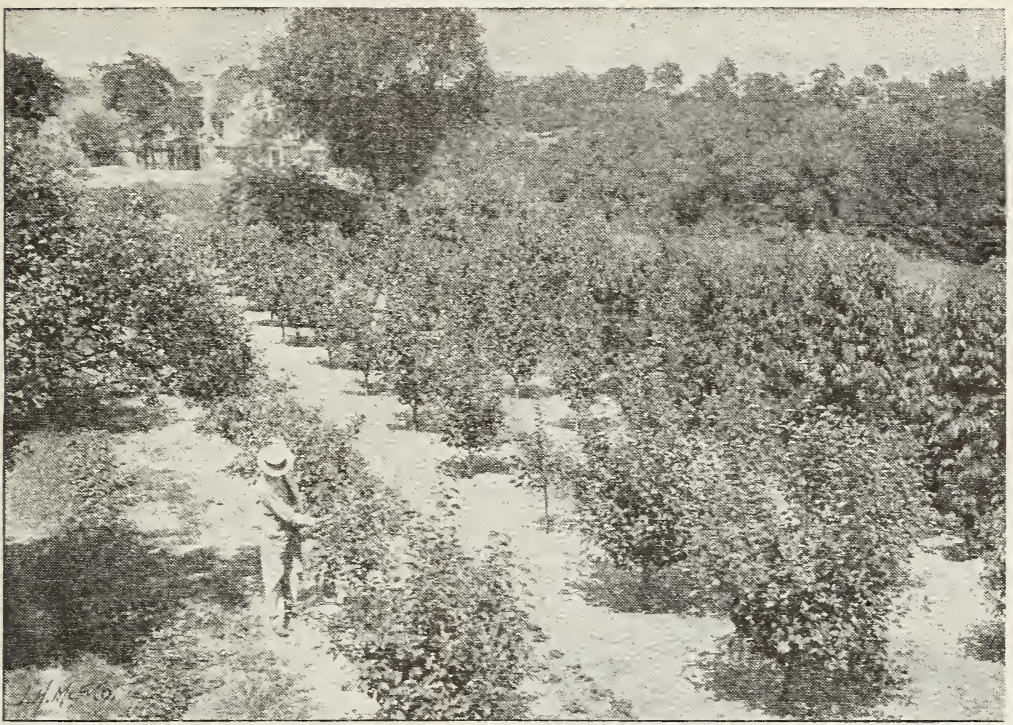

There are dollars and pleasure in a back-yard orchard. The bigger the orchard the bigger the results

their trees when they look like this, but it is a mistaken idea. Perhaps that overloaded tree will get tired of being worked too hard and the weight of th. fruit may break the branches. These heavy crops sap the life of the tree, and if allowed to mature all its fruit, you will get nothing but a short-lived tree at the most. Allow your trees to bear heavily this year, and next year you may have to be satisfied with less than half the crop.

It takes nerve to thin out the fruit, but if you want your trees to continue bearing until they reach old age, go over each one when the fruit is about the size of a dime. Pull off enough fruit so that the tree can comfortably carry its load. If you do this you may expect better results year after year.

\section{Persimmons}

This fruit is rapidly coming to the front as a really desirable semi-tropical introduction. The Japan varieties are the best, and when budded on our native varieties, they will grow and bear almost anywhere in the cotton belt, although not adapted to localities north of it.

In soil requirements, Persimmons are not unlike other deciduous fruits. A rich, soft soil will help the trees along wonderfully and increase the quality of the crops. The flesh of unripe fruits of the light-fleshed varieties is astringent or puckery. Dark-fleshed sorts are edible before they are fully ripened. An excellent way, and, so far as we know, the best way to ripen Persimmons is to allow them to hang on the tree until frost is near. Pick them then and take them into the house, where they ripen slowly and to the very center. This method gives a uniform flavor clear through the fruit. Do not think your Persimmons are ripe when they begin to color. Nearly all sorts color when about half grown and this does not indicate ripeness. 


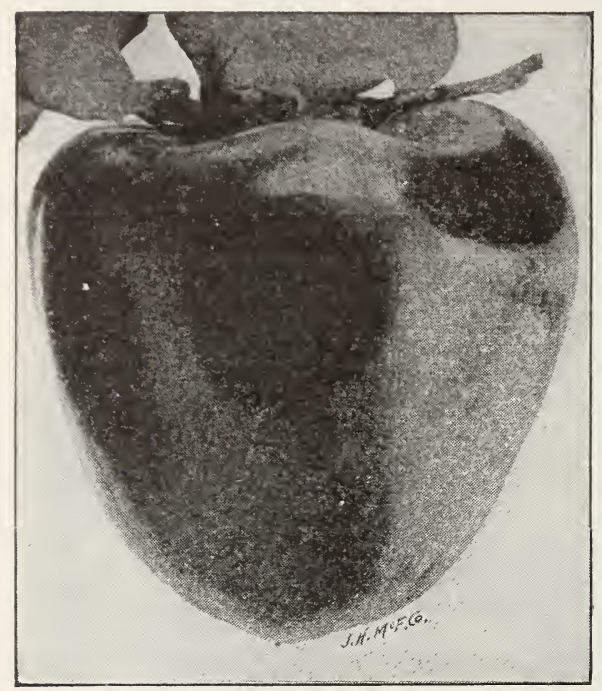

Persimmons should be planted in the South

A few years ago Persimmon trees showed a tendency to drop the half-grown fruit. This fault has been overcome and Persimmon-growing made profitable by the introduction of the Gailey variety. This sort is not recommended for its fruit, but for its pollenizing powers. A tree of the Gailey should be planted with every six or eight trees of other varieties to secure proper pollenation. Ask us for further information about planting or spraying Persimmon trees.

\section{Satsuma Oranges}

Satsuma is the hardiest edible Orange and in northern Florida and all the Gulf Coast region it should be extensively grown. The people living a hundred miles or more inland should turn their attention to other fruits, for Orange-growing is not advisable a greater distance from the Gulf.

A point in favor of the Satsuma for marketing purposes is its early ripening period. It is salable in September, and continues to ripen until November. At this time the big markets are very short on Oranges, for other varieties have not yet begun to ripen. On account of this condition, shipment of "Sats" invariably bring high prices.

In buying Satsuma Orange trees, be sure that you get them from a nursery with a clean bill of health from the inspectors, a certificate showing the trees absolutely free from citrus canker, a deadly enemy to all Orange trees.

\section{Cherries}

In the South, where nearly every growing thing does better than in colder climates, it is strange to find such choice fruit as Cherries among the trees that do not come up to their best. In the North, Cherries are at home, but the people of the South have come to consider them as partial failures and neglect to plant the trees. To a large extent this is due, not to the Cherry trees, but to the planters themselves. Cherries will grow in the South if the proper varieties are planted.

Unfortunately no variety has been found that will give entire satisfaction on the coast, but in the Piedmont and mountain sections the sweet Cherries will do fairly well. The most satisfactory varieties of this class are Tartarian, Wood, and Napoleon.

The sour Cherries will succeed in the Piedmont and mountain sections, and grow fairly well in the lowlands. There are four varieties, however, that stand way above all others for general planting. These are Richmond, May Duke, Morello, and Large Montmorency. Dyehouse is a fairly good sort. If planted in dry gravelly soil, these sorts should do well. Cherry trees will not live in wet ground. The earth does not have to be rich, and ordinarily almost any garden soil will be satisfactory to Cherry trees. 


\section{Mulberries}

Every bird-lover, owner of a chicken-yard, or raiser of hogs in the South should plant the Everbearing Mulberries. They fruit over a long period, come into bearing young, and produce abundantly. The trees will have fully ripened, half-ripened, and green fruit all at the same time, for their fruiting period extends over two months.

The birds fairly revel in them, while the dropping fruit is eagerly sought by chickens and hogs. If the birds are bothering you by eating your raspberries, strawberries, cherries, and other fruits, plant a Mulberry tree nearby. The best varieties (and all named are hardy from Virginia southward), are Abundance, Black English, Hicks, New American, and Downing. Of these, Abundance and Downing are the hardiest. Black English and Hicks are the best for the Carolinas, Tennessee, and all states farther south.

\section{Figs}

Figs are delicious, and every family garden should have a few trees. The fruit possesses a high market value and always finds a ready sale. The more noted varieties are Brown Turkey, Brunswick, Celestial, Lemon, and Magnolia. In the colder regions of the South, Celestial seems to be the most satisfactory for general planting. In the warmer sections all the varieties are good.

Fig trees should have a little winter protection in the colder sections. Plant them on the south side of a wall or building. An excellent place for the trees is in chicken runs, along the garden fence, near the hogpen, and around outbuildings. The soil should contain plenty of moisture and have good drainage.

\section{Apricots}

These are among the most delicious fruits that can be grown in the South. The fruit is about the size of the Japanese Plum, with a flavor fully as delicate as that of the peach. The principal difficulty in growing Apricots is the fact that the trees bloom in early spring' and, therefore, are likely to be injured by late frosts. The trees

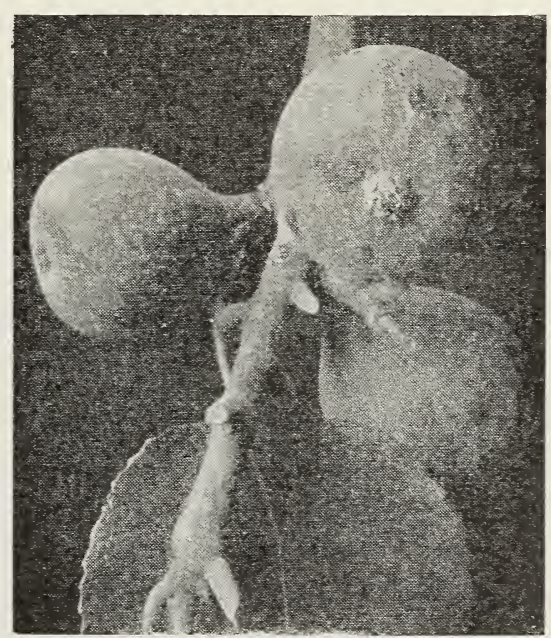

Figs are the oldest and one of the most delicious fruits growing in the South may be protected to some extent by planting them where they may receive the shelter of buildings, or where a windbreak of evergreens will temper the spring winds and ward off frosts. If it is possible to make a definite selection of land, it will be well to set the trees on the south side of a hill.

The varieties that are considered the best are Moorpark, Alexander, and Superb. These ripen in June and July, when other fruits are scarce.

If you don't fully understand the planting, care, and spraying of Apricots, write us. We are fully conversant with the fruit-grower's problems and will give you the benefit of our many years' experience. 


\section{Nectarines}

These are among the choicest fruits, and a perfect specimen is one of the most beautiful fruits that can be grown. There are several varieties planted, but New White, Red Roman, and Grady are usually considered the best. On account of the skin being so smooth, Nectarines are subject to attacks of curculio. The most effective way to keep this pest off is to spray, using the same compounds that should be used on peach trees. See instructions on page 32 . trees.

Soil and cultivation for Nectarines should be the same as given peach

\section{Quinces}

Another excellent fruit that is easy to grow is the Quince. It is one of the most desirable fruits for canning and preserving. Among the prominent varieties are Apple or Orange, Chinese, Champion, Meeche, Pineapple, and Rea. All of these are good, but Apple and Champion are considered a little superior for general planting.

The trees do better in heavy, clayey soils where the drainage is good. If the earth is wet or soggy, the fruit is quite likely to rot on the trees.

\section{Grapes}

Among the many small fruits it is hard to find any that are more desirable than Grapes. They can be grown in small space and in many of the tiny back yards in cities and villages. Grape-vines are desirable. They run over the fences, hiding them from view with their large, dark green leaves, and in the fall bearing bunches of the most delicious fruit one could ask for.

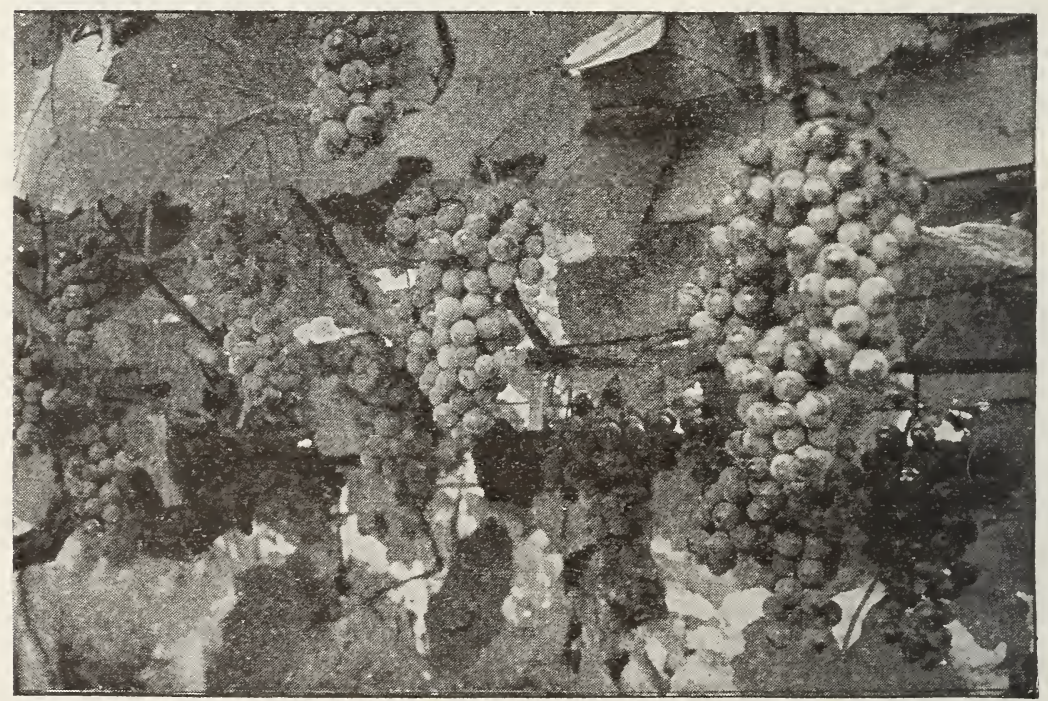

An arbor of Grape-vines is a necessity on the home grounds. It furnishes shade and fruit in abundance 


\section{SOUTHERN ORCHARD PLANTINGS}

Grapes are hardy and are perfectly at home anywhere between the Great Lakes and the Gulf of Mexico. Anyone can grow them successfully, for their cultivation is a simple matter. As a table delicacy Grapes cannot be surpassed and, if you sell your crop, you will always find a ready market and high prices.

There are many varieties of Grapes, but let us consider only those that have proved prolific and profitable in our Southern soil, climate, and conditions. The following varieties are named in their order of ripening: Moore is a large black Grape of poor quality, but is desirable on account of its early ripening. Delaware is light red, sugary and delightful; the best commercial Grape. Winchell is a white variety of excellent quality and flavor. Lutie is large and dark red. Brighton is an excellent red Grape. Niagara is the standard white sort. It has a delicious flavor. Concord is an old favorite. Its color is black. Catawba is the best late sort. In color it is bright red.

If you live in the lower South, the Grapes for you to plant are the Muscadine varieties. They are the most productive of all Grapes. These varieties seldom bear over ten berries to the bunch, but they make up in quality and size for what they lack in quantity, for the berries are usually about an inch in diameter and possess an unexcelled flavor. The following are the leading varieties and ripen in the order given: Thomas, Scuppernong, James, and Flowers.

Grapes may be grown on almost any well-drained soil. Plant the bunch varieties Io feet apart and the Muscadine types about I5 feet apart in rows Io feet apart, or on arbors 20 feet apart each way. Write to Washington for Grape Bulletins Nos. 284 and 47 I.

\section{Strawberries and Other Small Fruits}

Strawberries are considered the best of the small-fruit class, both for their food value and their delightful flavor. In North Carolina, Strawberries ripen in April. In fact, they are ready to eat before any other fruit. Coming in as early as this makes Strawberries excellent for market-growers. They are always in demand and good prices are cheerfully paid for choice fruit.

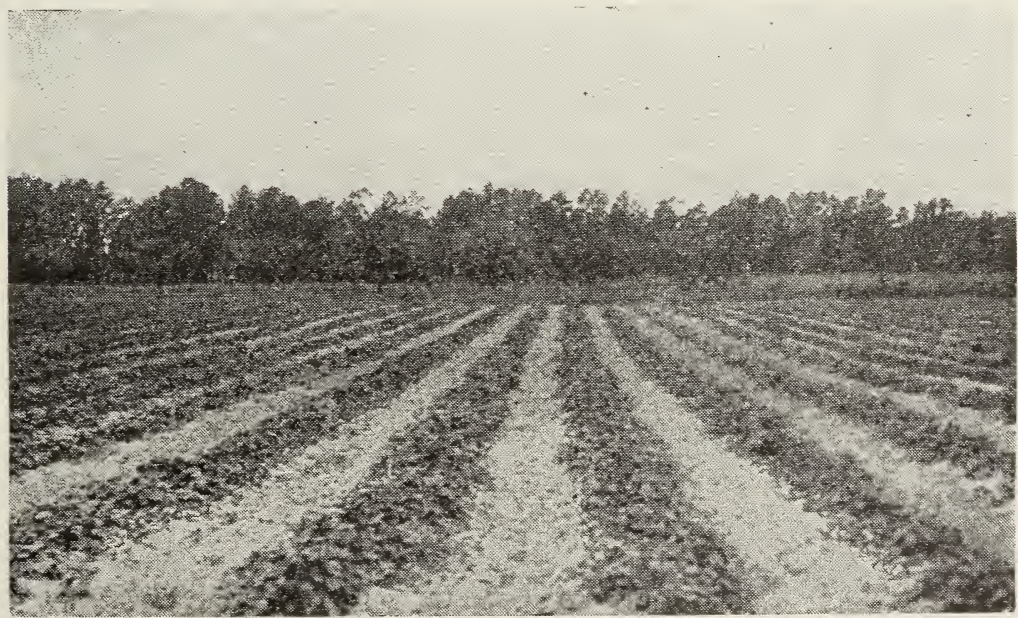

Strawberries are usually considered the best of all small fruits. They are easy to grow and profitable to the enterprising planter 
By selecting the proper varieties you can have fresh Strawberries from early spring until frost. Such a collection of equal value for either the home-gardener or market-grower would include the following sorts: Excelsior, Missionary, Lady Thompson, Klondyke, Greensboro Favorite, Bubach, Aroma, Gandy, and Chesapeake. Of course, there are other varieties, but the ones in the above list will give excellent results in the South. Almost any well-drained soil will grow Strawberries. Plant them from October to December, or during February and March, setting the plants about I5 to 20 inches apart each way.

Everbearing Strawberries. The Everbearing Strawberries are really the most important recent introduction. The plants. begin to bear in June or July and the berries keep coming until the blossoms are killed by the frost. Of the everbearing sorts Progressive is easily the best. A prominent horticultural authority says: "It is more than Progressive; it is the complete Strawberry." The berries are medium sized and their quality is excellent. While you are picking handsome, luscious berries, the plant you are picking from will have numerous unripe berries and several blossoms, all at the same time. However, Everbearing Strawberries do not do as well in the South as they do in the North.

Raspberries. After the earliest strawberries have come and gone, the

Raspberry is the next small fruit that comes into bearing. The leading red sorts for Southern planting are Cuthbert, Miller, Cardinal, and St. Regis. Among the blacks, Gregg, Cumberland, and Kansas are considered the best. Columbian is an excellent purple sort.

Raising Raspberries for either home or market is not difficult. They do well in almost any soil, but prefer a moist location where drainage is good. The red kinds like a light loam, and the black sorts seem to give best results in heavy loam. Set the bushes in rows 5 feet apart and 3 feet apart in the row. After your Raspberry plants have finished their year's fruiting, take a sharp knife and cut back the old canes to about a foot from the ground. This will cause a new growth and make your plants more productive.

Blackberries. Now let us consider another excellent small fruit-the

Blackberry. It is easy to grow, and for market or home use it is in high demand. Blackberries ripen in late summer, soon after raspberries. Well-known and desirable varieties are Eldorado, Erie, Early Harvest, Snyder, and Wilson. Cut out the old wood each year, the same as for raspberries.

Dewberries. The Dewberry is very delicious. It resembles the blackberry in form and color, but is higher in quality. Austin's Improved and Lucretia are the leading sorts. Dewberries should be trailed on low trellises or tied to a single stake to prevent the fruit from lying on the ground.

\section{When and How to Pick Fruit}

If you grow fruit, it will pay you to grow it well, for "a thing well done is twice done." If you aim to be a successful orchardist, you must pick the fruit at the proper time, regardless of whether you grow for home or market. Of course, there are different times for picking fruit and we could use a dozen pages if we wrote about all kinds. Just let us consider the leading classes, apples, peaches, pears, and plums.

Here is a good way to determine when your fruit is ready to pick. Lift them up, one at a time, give a gentle twist, and, if ready, the fruit will come away cleanly, stem and all. All fruit, except peaches and some varieties of plums, should be kept with the stem attached. This aids in marketing and adds to the keeping qualities. In fact, cherries will not keep unless the stems are attached to the fruits. 


\section{SOUTHERN ORCHARD PLANTINGS}

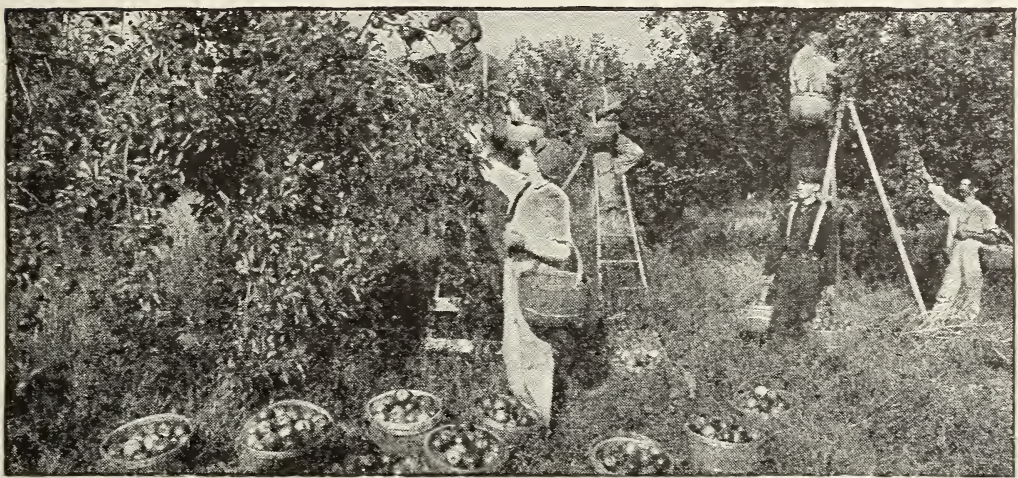

It pays to do everything right. When picking your fruit, be careful of both fruit and tree

Some varieties of pears should be picked a week or so before they become ripe. Bartlett, Seckel, and Kieffer are the kinds you should pick early, for they have a much higher quality when ripened in a cool, dark, airy room. The right time for picking depends, to some extent, on whether you grow for your own use or for market. If you are going to keep your crop, let all fruits except quinces mellow on the tree. If your crop goes to market, pick when the fruit is well colored but while it is still firm enough to stand shipping.

In taking the fruit from the tree, baskets will prove better than bags. The handle should be hinged so it will be easier to empty the fruit. Lay the fruit gently in the basket; do not drop it, for a bruise will cause rot to start almost at once.

Use a strong, light ladder, and lay it very gently into the tree so as not to break off any small limbs or fruit-spurs, thus reducing the prospects of a crop the following year. For dwarf apple and pear trees, a solid 3-foot bench and a step-ladder should enable you to get all the fruit.

Just as quickly as possible after removing the fruit from the tree, get it into a cool room. Do not allow the fruit to cool gradually in the orchard. Cool it quickly and it will improve the flavor and make it keep longer.

\section{How to Keep Fruit}

It is a well-known fact that fruit will not keep well unless it is properly cared for. It must be kept from frost, sudden weather changes, dampness, stagnant air, etc. The best and cheapest way to insure against loss of fruit after picking is to build a fruit cellar. Perhaps that sounds too expensive, but really it costs little. and, instead of being an expense, it is an investment that will pay dividends by keeping the fruit in better condition.

Here is a plan that will work out well. Make your cellar underground. That alone insures against sudden changes of temperature inside; it even excels cold storage. If there is a hill nearby, dig your cellar into the side of it. You do not need to have all the cellar underground. Build the outside section of concrete. At the back of the cellar you should have some means of ventilation. A drain-pipe a few inches across and extending up through the earth to the surface is the proper thing. This arrangement gives free circulation of air when the door is open. Let the air in at the bottom of the door and it will pass through the cellar and out of the pipe at the back. Do not put the fruit on the floor. Build shelves and put it on them. 
After the fruit is stored, keep the door closed during the day and open at night. Do this until November. After that just air out occasionally and the temperature will vary but slightly. During winter you will then find it an easy matter to keep the temperature of the storage or fruit cellar very close to the following figures which are recognized as correct: Apples, 39 degrees; cherries, 40 degrees; grapes, 36 degrees; nuts, 35 degrees; oranges, 36 degrees; pears, peaches, plums, prunes, and quinces, 35 degrees. All vegetables should be kept at about 35 degrees. Thus you will see that you can store almost all kinds of fruit at the same time in the same cellar.

\section{What to Do When Your Trees Come}

Many people have an idea that a tree will live and grow with any kind of treatment. When the trees arrive, if the land is not ready, or the planter is busy with other work, the trees are taken out of the box, examined, and then left to lie around for a few days. When a convenient time comes, the planter sets out the trees and expects them to start growth at once. Weeks pass without sign of life, and he wonders what can be the matter. He waits a while longer; still the trees show no inclination to grow. He then gets "hot under the collar," and blames the nurseryman for sending him dead trees. Perhaps he writes the man from whom he bought them telling him just how high he stands in the buyer's estimation.

Now that tree-buyer never stopped to consider his trees as living things. Either he did not know, or failed to remember, that tree roots should not be exposed to the air for any length of time. This neglect on the part of the planter was the sole cause of the loss. If he had taken just a few minutes to "heel them in," there would have been no cause for dissatisfaction.

You do not have to plant your trees just as soon as they get to you, but they must be given a chance to live. After they come, open the box or package and check them up to be sure none are missing. Now take the trees out and dig a trench about a foot deep (see illustration on this page). It shows how

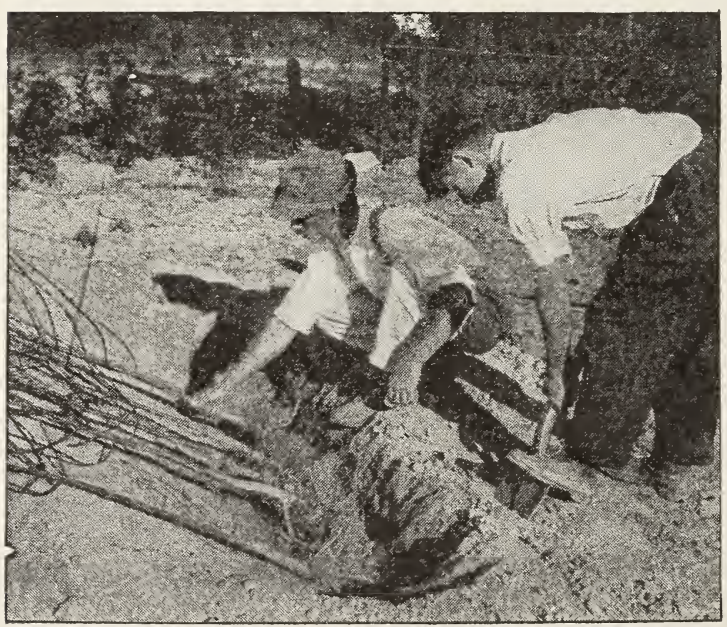

When your trees come, "heel them in" like this it should be done.

Lay the roots in this trench and cover with earth. Now the trees are safe until you get time to plant them, but it should be attended to soon. If your trees are frozen when they arrive, do not let that frighten you. Leave them in the box and either put the box in a cellar or bury it. Freezing does not greatly injure the trees; it is the alternate freezing and thawing $\mathrm{that}$ does the damage.

If your order is short, sit right down and write the nurseryman. Do not put it off. 


\section{SOUTHERN ORCHARD PLANTINGS}

\section{Planting the Trees}

Much of your success with an orchard depends on how well the trees are planted. When your trees arrive, get them into the ground as quickly as possible. If you are not quite ready to plant, "heel them in," as shown by the illustration; but the trees should not be left in the trench until root-growth starts. Set them out as quickly as possible.

Before planting, lay out the ground or orchard, allowing space enough so the trees will not crowd each other when fully grown. After laying out the grounds, the next thing is to dig the holes. Be sure to make them large enough. Many trees are injured by insufficient root room.

If the soil is soft, you can dig with a spade. If there is an underlying strata of hard sub-soil or shale, it should be broken up with dynamite. The concussion of the explosive will shatter the hard soil, making it easy for the roots to go through and increasing its drainage facilities. Dynamite is opening up a great field for the planter and grower. Drive a hole about 30 inches deep into the hard soil, using an iron bar. Put in one half of a I I/4 by 8 -inch cartridge of dynamite. This will not throw the soil, but will shatter the hard earth. The Dupont Powder Company, of Wilmington, Delaware, issue a useful book about dynamite on the farm. Ask them for "The Farmer's Handbook of Explosives."

After the holes are prepared, take the trees to the field, covering the roots with a wet blanket so the sun and air will not dry them out. Set the tree at about the same depth it stood in the nursery row. Hold the tree straight, shovel in some soil and see that it settles firmly about the roots, shaking the tree and pressing the soil with the feet or a tamper. Fill the hole even with the surface, but leave the top soil loose to act as a mulch and retain moisture.

Ornamental trees can be set in practically the same way, and if care is taken in planting, you can be almost certain that every tree will live and grow. The holes for ornamentals must be large enough to accommodate the roots without doubling them up or cramping them in any way. Set each tree at the same depth it stood in the nursery. Now put fine soil about the roots, firming it with the feet or tamper and later settling it by pouring on a pail of water. Fill up the hole but do not pack. Mulch with well-rotted manure. Planted this way your trees should thrive.

Evergreen trees should be planted the same way, taking great care that the roots are kept moist from the minute they are unpacked until they are in the ground. If the roots are wrapped in burlap, simply cut the strings and with a sharp knife slit the burlap in several places, and put the ball, burlap and all, in the hole. The burlap will soon decay. The tree should be watered regularly for a few days after planting.

Before setting out any growing thing, look carefully at the roots. If any have been bruised or broken in transit, take a sharp knife and trim the injured members. This does not hurt them in the least. Roses, however, require a little different treatment. Complete details for planting, pruning, aild care are given on page 13 .

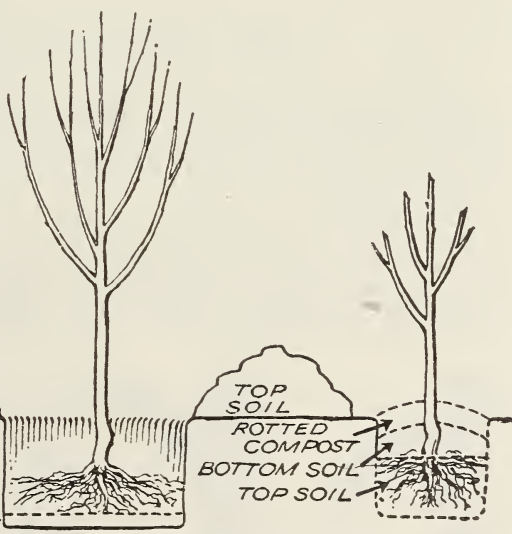

SOIL

Plant your trees this way and you will have little trouble 


\section{Pruning Fruit Trees}

Wherever you find a successful orchardist, you will find a man who knows how to prune his trees. Many people iail fully to understand the necessity for pruning fruit trees. Fruit production cannot be expected when the trees spend

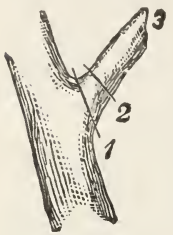

Fig. A

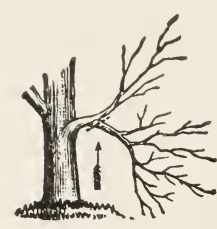

Fig. B all their strength and energy making branches and foliage instead of fruit.

After a young tree is set out, the form it will take depends on the amount of pruning it receives. This point must be determined by judgment and experience. The head of the tree should be open, to allow the sun the better to ripen the fruit. This form should be started by forming the head of the young tree when it is planted (see figure).

Pruning should also be done each year, when the trees are dormant. The best time is early spring, just as the sap is beginning to move upward. Wounds made at this time heal quickly.

For fruit-tree pruning, the best tool is an ordinary saw with an extra-wide set, so it will not bind in the green wood. The teeth ought to be fine, but it is not dangerous to use a coarse-toothed saw. Some people use long-handled pruning shears. These implements are not so good, for they crush the limb before cutting it. Such wounds are slow to heal.

A tree properly pruned has no unsightly stubs sticking out from either the trunk or the branches. These stubs are caused by not cutting closely enough, and very often do not heal cleanly. If the cut is made close to the trunk or branch, it will soon heal. After cutting, it is well to paint the wound. This keeps out the rain and prevents insects from getting at the wood. Always be careful with the pruning tool, so as not to leave any torn or ragged cuts.

Look at the diagrams on this page. They show the right ard wrong ways to prune fruit trees. Figure A shows where to cut; if cut at 3 , the result will be a long Figs. C stub and a wound slow in healing. It is better to cut at

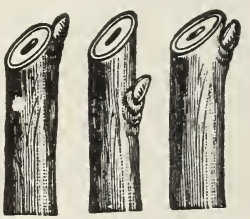

E 2 , but it is still too far from the trunk. Cut I is in the right place. This leaves no stub, and the new growth will quickly cover the wound.

Figure $\mathrm{B}$ shows how to remove a side branch. The arrow is pointing to a dotted line; cut at this line. Figure $\mathrm{C}$ shows how the cut can harm a bud; this is too low and no fruit will grow at the bud. Figure D is too high. Figure E is cut just right; it is far enough from the bud to allow it to set fruit, but is not too far away.

The method shown by Figure $F$ is injuring many trees. The man who made this cut started close up to the trunk and sawed down through. When the saw was nearly through, the weight of the branch pulled it downward, tearing the bark and trunk. This makes a wound that will be slow in healing, and may never heal entirely. Unhealed pruning wounds shorten the tree's life.

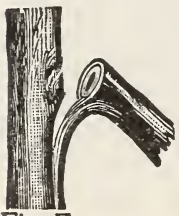

Fig. F

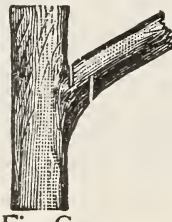

Fig. C

Figure $\mathrm{G}$ shows how Figure $\mathrm{F}$ should have been done. The first cut was made on the under side and went about half way through the branch. The saw was then started close to the trunk on the upper side of the branch. When the saw is half through the limb will break off cleanly. Then complete the job by sawing off the other half of the limb stub. This will leave a clean wound that will heal over quickly. 


\section{SOUTHERN ORCHARD PLANTINGS}

The amount of pruning required for different trees must be taken into consideration. The head of an apple tree should be liept open and all weak branches cut out each year. Watch for dead limbs and cut them out as fast as they appear. Do not let the tree fill up with small spindling branches. Aim to make the head low. Fruit can be gathered easily from low trees, and thus save picking expenses.

Pear trees must be pruned if you want a low tree. Otherwise they will grow straight up, and it will be more difficult to gather the fruit. Prune from the top. Cut above a bud that points outward. Do this every year for a few seasons and you will have an open-headed tree. Seckel pear trees do not require pruning. Leave them alone; they will do better.

Peach trees should be headed when young. Prune out the small branches. This directs the tree's energy toward fruit-making. Each spring go over your peach trees and cut out about one third the length of last year's growth.

Mr. W. N. Hutt, the State Horticulturist of North Carolina, gives the following pruning pointers: (I) Start the tree right; (2) Don't cut out large limbs; (3) Keep your tools sharp;

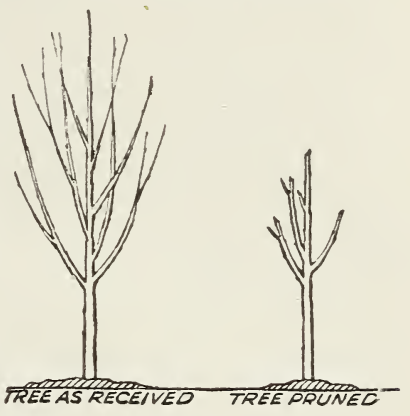
(4) Don't prune in freezing weather; (5) Leave no stubs-cut close to shoulder; (6) Prune annually but never heavily; (7) An axe or hatchet is not a pruning tool; (8) Do your pruning yourself; (9) Keep the tree free from suckers; (Io) Paint over the wounds; (II) Never allow your stock to prune trees. These simple instructions should be closely followed.

Hedges should not be trimmed too closely. Some will stand more than others. California privet and Thunberg's barberry can be trimmed short, but it is best not to go too close. Ordinarily a pair of pruning-shears, used two or three times during the summer, will be enough to maintain the shape you desire. If you prune but once a year, the young growth is apt to develop and you will have thick stubs left when you prune. By going over your hedge a few times during the summer months and keeping it even, you will have an excellent appearing hedge that will require but little care.

\section{About Spraying Fruit Trees}

The ravages of the numerous insects that attack fruit trees make it absolutely necessary to spray if profitable crops are looked for. Much of the imperfect fruit you so often see is directly traceable to insects that could be kept away by spraying. Sprayed fruit always brings better prices; so, if you intend to make a profit from your orchards, it will pay you to spray the trees and the fruit at the proper time.

Apple trees should be sprayed at least three times a year. The first spraying should be given in late winter. This will act against the pests that live on the tree over winter and awake to activity in early spring. For this first spraying, commercial lime-sulphur should be used. The mixture should be one gallon of the chemical to eight gallons of water.

The first spring spraying should be done as soon as the leaf-buds open. This will attack the early sucking insects that draw their sustenance from the sap of the tree through the bud. Commercial lime-sulphur should be used in the proportion of one and one-half gallons to fifty gallons of water.

The important spraying period is soon after blooming time, for it is at this stage that the codling moth lays its egg in the open flower, thus producing wormy fruit. The spray must be put on just when the blossom petals have fallen; if you wait longer, the poison cannot reach the insect. For this spray use a solution 


\section{SOUTHERN ORCHARD PLANTINGS}

of arsenate of lead, at the rate of about two pounds to fifty gallons of water. The lead may also be combined with bordeaux or other mixtures if desired. This spray should be applied at least once after the blooming time, and again ten days or two weeks later to kill the second brood of insects.

Peaches and plums seem to be more susceptible to attacks of San José scale than apples and pears. Spray in late winter, using the lime-sulphur solution. Put a gallon of chemical into every eight gallons of water. In addition to being effective against San José scale, this treatment also keeps off much fungous growth in addition to killing the insects.

Just after the blossom petals fall, you should spray with a weaker limesulphur solution, using the "self-boiled" mixture. To get best results, peach trees should be sprayed every two weeks until a month before the fruit ripens. This keeps all fungous growth in check and also prevents the other fruit-tree pests from getting a foothold. Curculio, that pest of the peach-and plumgrower, can be kept away by spraying with arsenate of lead. Just after the blossoms fall use arsenate with "self-boiled" lime sulphur, and repeat the "dose" ten days later.

Pear trees as a rule do not require as much spraying as apples or peach trees. Two sprayings are usually sufficient. The first application should be when the trees are dormant. Fall, winter, or early spring is the best time, but it is not advisable to do it when the temperature is below the freezing point. The mixture to be used is one gallon of lime-sulphur to eight gallons of water. The second spraying of pear trees should be done just after the blossoms fall. Use lime-sulphur, one and one-half gallons to every fifty gallons of water, adding two pounds of arsenate of lead. For more detailed spraying information, write your State Entomologist at the state capital, or your State Agricultural College. The United States Department of Agriculture issue bulletins on spraying. Write to Washington for list of bulletins.

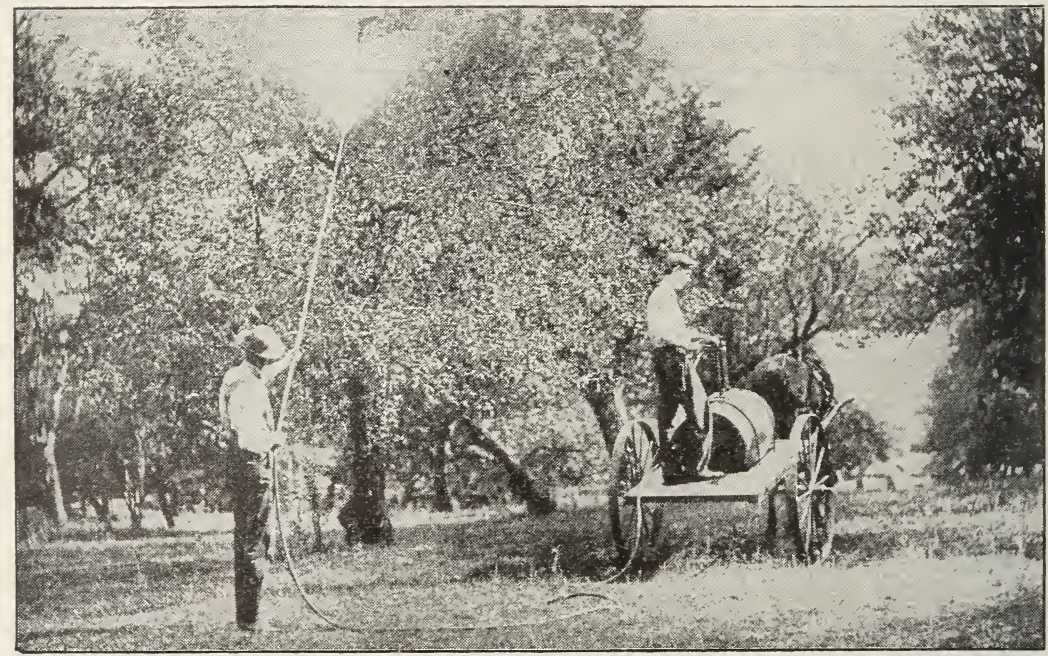

Be sure to get a sprayer that fills your needs. If your orchard is small, a hand sprayer will do; if the orchard is large, get a power sprayer 


\section{Greensboro Nurseries}

John A. Young \& Sons, Owners GREENSBORO, NORTH CAROLINA 